\title{
Investing in the 'New Economy': Mutual Fund Performance and the Nature of the Firm
}

\author{
Swasti Gupta-Mukherjee \\ Loyola University Chicago, sguptamukherjee@luc.edu
}

Follow this and additional works at: https://ecommons.luc.edu/business_facpubs

Part of the Business Commons

\section{Recommended Citation}

Swasti Gupta-Mukherjee (2014). Investing in the "New Economy": Mutual Fund Performance and the Nature of the Firm. Journal of Financial and Quantitative Analysis, 49, pp 165-191. doi:10.1017/ S0022109014000179.

This Article is brought to you for free and open access by the Faculty Publications and Other Works by Department at Loyola eCommons. It has been accepted for inclusion in School of Business: Faculty Publications and Other Works by an authorized administrator of Loyola eCommons. For more information, please contact ecommons@luc.edu.

\section{c) (i) $\ominus$}

This work is licensed under a Creative Commons Attribution-Noncommercial-No Derivative Works 3.0 License. (c) 2014 Michael G. Foster School of Business, University of Washington. 


\title{
Investing in the 'New Economy':
}

\section{Mutual Fund Performance and the Nature of the Firm}

\author{
Swasti Gupta-Mukherjee* \\ Quinlan School of Business \\ Loyola University Chicago \\ 1 E. Pearson St \\ Chicago, IL 60611 \\ Phone: 312-915-6071 \\ e-mail: sguptamukherjee@luc.edu
}

September 7, 2012

Journal of Financial and Quantitative Analysis, forthcoming

\footnotetext{
* I am thankful to Stephen Brown (the editor), Susan Chaplinsky, Jinyi Fu, David Hirshleifer, Sonya Lim, Tom Nohel, Steven Todd, and especially an anonymous referee for helpful suggestions at various stages of the paper. This research was supported by the Faculty Development Grant and the Center for Risk Management at Loyola University Chicago. All remaining errors are my own. This paper was previously circulated under the title "Investing in the 'New Economy': Intangibles and Mutual Funds".
} 


\title{
Investing in the 'New Economy':
}

\section{Mutual Fund Performance and the Nature of the Firm}

\begin{abstract}
Although stock returns of intangibles-intensive firms tend to exceed physical assets-intensive firms, risk-adjusted returns of actively managed mutual funds significantly decrease (increase) with their portfolios' exposure to intangibles-intensive (physical assets-intensive) firms. Fund managers tend to exhibit skill when they focus on difficult-to-value (e.g. small) firms, except when the firms are intangibles-intensive. In sum, the worst-performing funds are in areas of the market which seem to offer ample opportunities for professional investors due to exacerbated mispricing. The negative impact of investments in intangibles-intensive firms on fund performance appears to be driven by extrapolation bias and decreases with learning from experience.
\end{abstract}

KEYWORDS: mutual fund performance, intangible assets, physical assets, research and development (R\&D), behavioral bias, learning

JEL Codes: G11, G14, G23, O33 


\section{Introduction}

In the last two decades, the U.S. (United States) economy has been marked by the spectacular growth of intangibles-intensive firms founded on innovation and human capital. Prior to this, the economy was largely dominated by the physical assets-intensive firms that emerged following the second industrial revolution of the late 1800s (see Zingales (2000)). Several strands of research postulate on the implications of the changing nature of the firm in this "new economy". Rajan and Zingales (2000) and Rajan and Wulf (2006) underscore the changes in governance and flattening organizational structure, while others suggest that the valuation of modern firms is more opaque and less related to traditional financial variables (Core, Guay, and Buskirk (2003)). Some studies point to the market's misvaluation of intangibles, alluding to limitations in the valuation techniques honed based on the physical assets-intensive firm of the $20^{\text {th }}$ century. ${ }^{1}$ More generally, given the relatively recent emergence of industries that prioritize intangibles like human capital and innovation, investors may value physical assets more accurately due to learning from historical experience and data. ${ }^{2}$

In spite of ample evidence suggesting that the nature of the firm could affect investors' ability to value firms, how it affects the actual returns earned by portfolio investors has remained unexplored. In this study, I examine the relation between the nature of the firm and the returns earned by a welldefined class of stock market investors- actively managed equity mutual funds. There are at least two reasons why the impact of the nature of the firm on mutual fund returns is an interesting topic to study. Firstly, intangibles-intensive firms now form a sizeable segment of capital markets. Coupled with the remarkable growth of the active portfolio management industry, any impact the nature of the firm has

\footnotetext{
${ }^{1}$ Studies that find misvaluation of intangibles have focused on innovative inputs like R\&D (e.g. Eberhart, Maxwell, and Siddique (2004), Cohen, Diether, and Malloy (2010)), innovative outputs like patents (Hirshleifer, Hsu, and Li (2010)), and employee satisfaction (Edmans (2011)).

${ }^{2}$ See Seru, Shumway, and Stoffman (2009), and Greenwood and Nagel (2009) for evidence of learning among investors.
} 
on abnormal returns of mutual funds is economically meaningful information for investors during the selection of mutual funds, for academics interested in market efficiency, and for other stock investors during security selection. Secondly, return predictability and whether fund managers are skilled "arbitrageurs" who can exploit mispricing or unskilled investors who underperform passive benchmarks have remained strongly debated issues in the literature since Jensen (1968). Since return predictability and the skill required to identify mispricing could vary with the nature of the firm, it is a novel and potentially valuable lens through which to view skill in active management.

Several recent studies argue that some mutual fund managers possess skill and add value in active management (see Wermers (2000), Kacperczyk, Sialm, and Zheng (2005), Kacperczyk, Sialm, and Zheng (2008), Cremers and Petajisto (2009)). ${ }^{3}$ Additionally, to the extent that intangiblesintensive firms are associated with higher information asymmetries, intangible and uncertain valuerelevant information, as well as deferred resolution of uncertainty related to the long term value of investments like research and development $(R \& D)$, the studies on investors' behavioral biases predict that these firms are more susceptible to misvaluation than traditional firms. ${ }^{4}$ Existing empirical evidence is consistent with this view and suggests that intangibles-intensive firms are undervalued by

\footnotetext{
${ }^{3}$ Given the vastness of the literature on mutual fund performance, it cannot be comprehensively summarized here. Some other studies that find evidence of performance persistence and skill among mutual funds are Grinblatt and Titman (1992), Daniel, Grinblatt, Titman, and Wermers (1997), Bollen and Busse (2004), Cohen, Coval, and Pastor (2005), Kosowski, Timmermann, Wermers, and White (2006), and Kacperczyk and Seru (2007). Examples of representative studies with contrasting evidence include Brown and Goetzmann (1995), Carhart (1997), and Fama and French (2010) who conclude that mutual fund managers create little or no value with their skill, especially net of fees.

${ }^{4}$ Aboody and Lev (2000) and others argue that there are higher information asymmetries in intangibles-intensive firms. Daniel, Hirshleifer, and Subrahmanyam (DHS) (1998, 2001), and Daniel and Titman (2006) predict that investors are more prone to exhibit biases when the information is intangible and uncertain. Moreover, these effects are strongest when the outcomes are deferred (Einhorn (1980)) and information asymmetry is higher (DHS (1998), Hong and Stein (1999)).
} 
the market and offer more opportunities for informed investors, e.g. insiders in Aboody and Lev (2000), than physical assets-intensive firms. ${ }^{5}$ So, informed fund managers could tilt their portfolios towards intangibles-intensive firms to exploit mispricing and earn higher abnormal returns. Here, fund performance is likely to have a positive relation with the degree to which the fund's portfolio is tilted towards intangibles-intensive firms as opposed to physical assets-intensive firms.

Alternatively, fund managers, like other investors, may exhibit behavioral biases in processing complex and intangible information (e.g. Jiang (2010)). More generally, Griffin and Tversky (1992) posit that biases like overconfidence are more likely to be exhibited by experts than non-experts when faced with ambiguous and uncertain information. In addition, fund managers' skill in identifying mispriced firms could increase with learning and the availability of historical data, wherein they should have better valuation techniques for physical assets-intensive firms than intangibles-intensive firms. These notions suggest that fund performance is likely to have a negative relation with the degree to which the fund's portfolio is tilted towards intangibles-intensive firms as opposed to physical assetsintensive firms. To summarize, existing theoretical and empirical evidence presents alternative predictions on the potential link between the nature of the firm and mutual fund performance.

Innovative inputs like $R \& D$, which this study mainly focuses on with respect to intangibles, play a substantial role in the valuation of modern firms. To characterize the nature of the firms a fund invests in, I mainly use a measure called the Intangibles Intensity Ratio (IIR). The IIR is the valueweighted R\&D-to-PPE expenses ratio of individual firms in a fund's portfolio, with the fund's tilt towards intangibles-intensive firms and away from physical assets-intensive firms increasing with IIR.

\footnotetext{
${ }^{5}$ Eberhart, Maxwell, and Siddique (2004), Hirshleifer, Hsu, and Li (2010), and Cohen, Diether, and Malloy (2010) document the underpricing of innovative firms, and argue that investors' cognitive limitations in assessing intangibles lead to their underpricing. Alternatively, Chambers, Jennings, and Thompson (2002) argue that omitted risk factors explain the seeming underpricing of these firms.
} 
The IIR is stable over time and contains information distinct from a fund's style (e.g. value versus growth), self-stated objective, and other fund attributes.

Further, funds tilted towards intangibles-intensive firms earn substantially lower abnormal returns on average than funds tilted towards physical assets-intensive firms. For the main analyses, funds are assigned to deciles based on IIR in the prior quarter, where the lowest Decile 1 (highest Decile 10) portfolio generates significantly positive (negative) alphas in the following quarter. The IIR Decile 1-10 four-factor alpha is $2.85 \%$ per year. The return patterns persist for at least three years following portfolio formation. The results are consistent with fund managers focused on physical assets-intensive firms exhibiting more skill than those focused on intangibles-intensive firms.

To rule out an important alternative interpretation that a fund's $I I R$ simply proxies for omitted pricing factors, the tests are sharpened by augmenting the factor models. A factor mimicking Intangibles-Minus-Tangibles (IMT) portfolio that is long on stocks of high R\&D-to-PPE firms and short on stocks of No-R\&D (i.e. zero R\&D) firms is used to augment factor models. The passive IMT portfolio yields a positive monthly return of $1.63 \%$, due to either the relative underpricing or risk of high R\&D versus No-R\&D firms. Adding the $I M T$ factor strengthens the results, with the four-factor model augmented with IMT yielding an IIR Decile 1-10 alpha of $6.54 \%$ per year. Results remain robust across other tests accounting for omitted factors and across alternative risk adjustment methods.

Before-cost measures of fund manager skill, like gross returns and Characteristic Selectivity (see Daniel et al. (1997), Wermers (2000)) provide conclusions similar to net returns. Interestingly, funds with high IIR exhibit poorer stock selection ability than those with low IIR in their intangiblesintensive as well as physical assets-intensive holdings. The results survive various robustness tests that include using alternative measures of innovation-related intangible assets (e.g. patents), controlling for past intangible and total stock returns, and multivariate regression settings. 
The empirical analyses also separate the effect of the nature of the firm from the effects of general information problems linked to difficult-to-value firms. Fund managers outperform (underperform) when they focus on physical assets-intensive (intangibles-intensive) difficult-to-value firms. Resonating with Jensen's (1993) premise that investors may overvalue R\&D due to the uncertainty in its longer term outcomes, and Daniel and Titman's (2006) prediction that investors misreact to intangible information, these results can be construed as fund managers overpaying for the long-term benefits of intangible innovative assets of difficult-to-value firms (e.g. small, growth firms).

Further, fund managers' trend-chasing extrapolative behavior increases with their focus on intangibles-intensive firms and, consistent with extrapolation bias, this behavior is detrimental for fund performance. Also, the extrapolation bias and the negative impact of IIR on returns decreases with a fund's prior experience. In light of the much longer historical presence of firms with physical assets, and existing evidence that extrapolation bias decreases with investor experience and data, these findings are consistent with the nature of the firm being associated with behavioral biases that affect fund managers and decrease with learning. ${ }^{6}$ This evidence fits well with the growing literature which shows that behavioral biases affect institutional investors (e.g. Frazzini (2006), Jiang (2010)), and lends fresh insights to the recent literature on the role of learning in institutional trading (see Greenwood and Nagel (2009)).

Finally, a fund's maximum payoff and volatility increases, and mean-variance efficiency decreases with IIR. So, the nature of the firm impacts the welfare of fund investors via multiple channels and could be linked to investor preferences in the selection of mutual funds.

\footnotetext{
${ }^{6}$ For studies linking forecasting errors from extrapolation bias to investor inexperience and lack of data, see Rabin (2002), Hong, Stein, and Yu (2007), Haruvy, Lahav, and Noussair (2007), and Greenwood and Nagel (2009).
} 
To summarize, by using the easily observable nature of the firm to predict fund returns and identify the environments in which fund managers are likely to act as informed versus uninformed agents, this study contributes to the literature on informed trading and active portfolio management. The role of the nature of the firm in predicting outperformance and underperformance presents an interesting empirical coexistence of the conflicting ideas on skill in active management, namely the view of fund managers as informed investors versus uninformed investors who fail to beat benchmarks. It is also an intriguing paradox that the delegated portfolios perform most poorly in the areas of the market which seemingly offer the most opportunities for professional investors due to exacerbated information problems and mispricing.

The paper proceeds as follows. Section II discusses the data and sample. Section III defines the main variable used to capture the nature of the firms held in mutual funds' portfolios. Section IV presents the empirical results. Section V concludes.

\section{Data and Sample Selection}

The data used in this paper mainly draw from two mutual fund databases: CRSP Survivor-bias Free US Mutual Fund Database (MFDB) and Thomson Financial holdings database. The initial sample consists of all unique funds that appear in CRSP MFDB over 1980 to 2009. The CRSP data on monthly returns, fees, and other fund characteristics are obtained. ${ }^{7}$ The sample is then matched to the holdings database using a combination of the MFLINKS interface (see Wermers (2000)) and hand-matching, and funds located in the U.S. are selected. While some funds report holdings semiannually as per mandatory disclosure requirements, Wermers (2000) notes that most mutual funds report holdings on a

\footnotetext{
${ }^{7}$ CRSP MFDB often includes multiple identifiers for the same fund if it has different share classes. I eliminate duplicate observations by first identifying the fund identifier with the longest time series of returns. If this step does not identify a fund uniquely, the identifier associated with the highest TNA in the year prior to the return observation is selected.
} 
quarterly basis since 1980. I exclude funds with less than $\$ 10$ million in total net assets (TNA) as reported in Thomson Financial and various screens are then employed to select actively managed diversified domestic equity funds. ${ }^{8}$ Finally, since the analyses are based on holdings that can be matched to CRSP's stock files, I select funds for which the market value of the reported holdings represent at least $65 \%$ of the quarter-end TNA. To these holdings data, I merge firm level data from the annual COMPUSTAT files, like R\&D expenses (Item 46) and PPE (Item 8). ${ }^{9}$

The final sample used in this study includes 3,165 unique actively managed U.S. equity mutual funds during the period 1980 to 2009 . The funds map to 98,231 unique fund-quarter observations for portfolio holdings, and 285,419 monthly return observations. The mean (median) fund in the sample has a TNA of $\$ 952$ million (\$170 million). The number of funds has grown substantially over time with 216 unique funds with observed holdings in 1980, and 1,502 in 2009.

\section{Measuring Mutual Funds' Portfolio Concentration in Intangibles}

This section describes the main measure used to characterize the nature of the firms held by mutual funds, called the "portfolio concentration in intangibles". Time trends in portfolios are also reported.

Prior studies like Brown, Fazzari, and Peterson (2009) have noted that the R\&D activities of publicly traded U.S. companies experienced a boom starting in the early 1990s. Based on two measures, Figure 1 graphically illustrates the time trend in mutual funds' portfolio concentration in

\footnotetext{
${ }^{8}$ Index, sector, bond, international, and money market funds are excluded based on stated objectives or using keywords in the fund's name. Funds which have objectives defined as aggressive growth, growth, growth and income, equity income, growth with current income, income, long-term growth, maximum capital gains, small cap core/growth/value, large cap core/growth/value, mid cap core/growth/value, multi cap core/growth/value, unclassified, or missing are chosen.

${ }^{9}$ Unlike some other voluntary disclosures (e.g. advertising), the SFAS 2 rule requires firms to report R\&D expenses separately. So, firms which are missing R\&D expenses data in COMPUSTAT are noted as having zero R\&D expenses.
} 
intangibles. The measures are presented as equal-weighted means across all funds in all quarters in a calendar year. Graph A of Figure 1 plots the main measure of a fund's portfolio concentration in intangibles used in this study- the Intangibles Intensity Ratio (IIR). A fund's IIR in quarter $t$ is the value-weighted ratio of R\&D expenses to PPE expenses of the firms held in the portfolio, computed as

$$
I I R_{t}=\sum_{s=1}^{N} w_{s, t}(R \& D / P P E)_{s, t}
$$

Here $w_{s, t}$ is the portfolio weight of stock $s$ in quarter $t$ in the fund's portfolio of $N$ stocks. Since R\&D expenses are usually disclosed annually, $(R \& D / P P E)_{s, t}$ is the ratio of R\&D-to-PPE expenses of firm $s$ in the most recent year before $t$. The higher (lower) the IIR of a fund, the higher is the fund's concentration in intangibles-intensive (physical assets-intensive) firms. Graph B of Figure 1 plots the value-weighted ratio of R\&D expenses to sales (COMPUSTAT Item 12), where R\&D expenses to sales is a popular measure of R\&D intensity.

Graph A of Figure 1 shows a visible upward trend in IIR. While in the early 1980s, the implicit R\&D expenses were less than $10 \%$ of PPE expenses in the firms held by mutual funds, this number has typically been around 40\% post-2002 and remains about four times the level in the early 1980s even in the global recession of 2008-2009. Graph B also reinforces the growing exposure of mutual fund portfolios to firms with intangible assets.

Table 1 presents summary statistics on portfolio holdings using additional measures of mutual funds' exposure to firms with intangible assets for the full sample (Panel A) and for selected fund Table objectives (Panel B). Various measures are reported over 1980 to 2009, and also for four sub-periods. In Panel A, the mean IIR for the full sample is $30.8 \%$. The two most conspicuous trends in the portfolios are the IIR and Total Intangibles-to-PPE ratio, which increase from $11 \%$ to $37.4 \%$ and $15 \%$ to $208.4 \%$ between the earliest and the last period, respectively. In Panel B, there is substantial dispersion in IIR across objectives, but the growth in IIR over time is noticeable within all objectives. 
Table 2 presents panel regressions predicting IIR. The $p$-values are from Newey-West standard errors with a lag length of three quarters and clustered by fund. Consistent with time-related stability, Table $2_{\text {here }}^{\text {Tat }}$ Past IIR, i.e. the fund's average IIR in the prior four quarters, explains a substantial part $(=49.2 \%)$ of the variance in IIR in column (1). Objective and year fixed effects in column (2) add some incremental explanatory power (4.8\%) beyond Past IIR. In column (3), variables that capture a fund's style (Size Score, Book-to-Market Score, and MOM Score) are used to explain IIR. These variables are computed for a fund as the value-weighted Daniel et al. (hereafter DGTW) (1997) size, book-to-market, and momentum quintile across the firms in the portfolio. ${ }^{10}$ Column (3) shows that funds with higher IIR have portfolios tilted towards small, growth, and momentum stocks. However, along with year and objective dummies, the style measures only explain $36.4 \%$ of the variance in $I I R$. The significantly positive relation between IIR and MOM Score shows that funds which focus on intangibles-intensive firms tend to follow trend-chasing (i.e. extrapolative) strategies. Since existing studies like Haruvy, Lahav, and Noussair (2007) show that extrapolative behavior diminishes with investor experience, it is plausible that the positive relation between IIR and trend-chasing diminishes with prior experience. In column (4), two variables that proxy for a fund's prior experience, log (Fund Age) and log (Manager Tenure), are included along with their interactions with MOM Score. The significantly negative coefficients on MOM Score x log (Fund Age) and MOM Score x log (Manager Tenure) suggest that trend-chasing in intangibles-intensive investments decreases with prior experience. Note that these tests do not directly address whether the trend-chasing by funds focused on intangibles-intensive firms is based on rational expectations or extrapolation bias. This issue is examined later in Section IV.G.

The following fund attributes also known to be related to performance are added in columns (5) and (6): fund size ( $\log (T N A))$, fund flows over the three months in the quarter (Past Flows), Expense

\footnotetext{
${ }^{10}$ I am grateful to Russ Wermers for making the DGTW (1997) stock benchmark data available.
} 
Ratio, Turnover Ratio, Industry Concentration, and Active Share (see Cremers and Petajisto (2009)), where the latter four measures reflect activeness. ${ }^{11}$ Industry Concentration is computed as the sum of squared portfolio weights in the ten industry categories in Kacperczyk, Sialm, and Zheng (2005). In general, funds with less experienced managers, higher turnover, recent outflows, and higher industry concentration tend to have higher IIR. Comparing the $\mathrm{R}^{2}$ of the most inclusive model in column (6) with column (1), Past IIR has by far the most explanatory power over IIR.

\section{Empirical Results on Mutual Fund Performance}

This section examines the link between $I I R$ and the performance of actively managed funds.

\section{A. Performance Measurement}

To begin examining fund performance, I first assign each fund to a decile portfolio $p$ at the end of quarter $t$ based on its IIR. In each month in quarter $t+2$, decile portfolio $p$ 's excess return $\left(r_{p, t}\right)$ is computed as the equal-weighted mean excess return of the funds in the portfolio. ${ }^{12}$ The performance of each decile portfolio (re-formed quarterly) is then evaluated based on various factor adjustment models, with the most inclusive specification being the following five-factor model

$$
r_{p, t}=\alpha_{p}+\beta_{p}^{M K T}\left(R M_{t}-R f_{t}\right)+\beta_{p}^{S M B} S M B_{t}+\beta_{p}^{H M L} H M L_{t}+\beta_{p}^{M O M} M O M_{t}+\beta_{p}^{L I Q} L I Q_{t}+\varepsilon_{p, t}
$$

${ }^{11}$ Following prior studies, the fund flows in month $t$, i.e. the growth in TNA due to new investments, is calculated as

$$
\text { Flow }_{t}=\frac{T N A_{t}-T N A_{t-1}\left(1+R_{t}\right)}{T N A_{t-1}}
$$

where, $R_{t}$ is the monthly net return of the fund during month $t$, and $T N A_{t}$ is the fund's total net asset value at the end of month $t$ as reported in CRSP. Outliers are eliminated by winsorizing the $2.5 \%$ tails.

${ }^{12}$ The returns for the decile portfolios are observed in the following quarter $t+2$ to allow for the portfolio holdings to become public sometime during the three months following quarter $t$ (see Kacperczyk, Sialm, and Zheng (2008)). This additional implementation lag does not affect the results substantially since the $I I R$ measure is persistent over time. 
Here $\left(R M_{t}-R f_{t}\right)$ is the monthly return on a value-weighted market proxy portfolio minus T-bills; $S M B_{t}, H M L_{t}, M O M_{t}$, and $L I Q_{t}$ are returns on factor-mimicking portfolios for size, book-to-market, momentum, and liquidity (see Fama and French (1993), Carhart (1997), Pastor and Stambaugh (2003)). ${ }^{13}$ Each portfolio's factor loadings $\left(\widehat{\beta}_{p} s\right)$ in month $t$ are obtained from time series regressions over a 36-month window $t$-36 to $t$-1. The abnormal return, or alpha, for decile portfolio $p\left(\alpha_{p}\right)$ is then computed as the monthly excess return minus the product of the factor loadings and factor realizations in month $t$. Results are generally presented for multiple factor models which vary in the regressors.

Table 3 reports the mean $I I R$ and factor loadings of the IIR decile portfolios. Column (1) reveals considerable dispersion in IIR between Decile 1 (Low) and Decile 10 (High). The implicit here R\&D expenses are 3.3\% (68.6\%) of PPE on average for Decile 1 (Decile 10). The factor loadings in columns (2)-(6) show that funds with higher IIR tend to be more cyclical, comove more with small cap, growth, and momentum stocks, and have less exposure to liquidity risk than funds with lower IIR. Indicating strong persistence in the nature of the firms held by a fund, $96.8 \%(96.4 \%)$ of funds ranked in IIR Decile 1 (Decile 10) in the ranking quarter $t$ remain within one rank of the assignment in quarter $t+1$ (column (7)). The funds' movement across decile ranks remains low beyond $t+1$.

\section{B. Baseline Results}

Table 4 reports fund performance using the portfolio level approach in columns (1)-(4), and an alternative fund level approach in columns (5)-(8). The Decile 1-10 returns represent a zero- $\begin{aligned} & \text { Insert } \\ & \text { Table } 4 \\ & \text { here }\end{aligned}$ investment strategy that goes long (short) on funds tilted towards physical assets-intensive (intangibles-intensive) firms. Overall, the funds tilted towards intangibles-intensive firms significantly underperform the funds tilted towards physical assets-intensive firms. For instance, in column (1), the

\footnotetext{
${ }^{13}$ I am grateful to Kenneth French and Lubos Pastor for providing the factor data.
} 
lowest IIR decile outperforms the highest IIR decile by a statistically significant $4.32 \%$ per year in terms of the one-factor alpha. The three-, four-, and five-factor alphas of the Decile 1-10 portfolio are statistically and economically significant at $1.79 \%, 2.85 \%$, and $2.67 \%$ per year, respectively. These results can be attributed to the underperformance of high $I I R$ funds combined with the outperformance of low IIR funds. The alphas appear to decline with increasing IIR deciles nearly uniformly.

In columns (5)-(8) of Table 4, I estimate the risk-adjusted returns at a fund level. Here, a fund's factor loadings in month $t$ are obtained from regressing the fund's monthly excess returns on the benchmark factors over $t-36$ to $t$ - 1 . The mean fund level alphas across funds in each decile portfolio averaged over all the months are reported and provide similar conclusions. The results so far are consistent with mutual fund managers exhibiting more skill when they focus on traditional physical assets-based firms than when they focus on modern intangibles-intensive firms. Hereafter, the results of non-parametric analyses are reported using the portfolio approach, but are robust to using the fund level approach and other commonly used risk-adjustment methods. ${ }^{14}$

\section{C. $\quad$ Omitted Factors, Stock Returns, and IIR}

An important concern in interpreting the central results is whether there are omitted systematic risk or mispricing factors common to the types of stocks held by funds which vary in their IIR. In this case, it

\footnotetext{
${ }^{14}$ In unreported robustness checks, results remained unchanged on using two additional risk adjustment methods. First, the alpha of each decile portfolio equaled the intercept of the time series regression of the monthly portfolio excess returns on common risk factors. Second, the alphas for each decile portfolio are computed following the two-step Fama and Macbeth (1973) method, where cross-sectional regressions are run in each time period for each decile on common risk factors, followed by time series tests to determine the alphas from the intercepts. These additional methods serve to confirm the results when risk is adjusted by in-sample estimations which could be important when R\&D investments can change a firm's systematic risk (see Berk, Green, and Naik (2000)). The results are available upon request.
} 
is not straightforward to interpret the main results as fund managers of funds with low IIR exhibiting more skill in generating abnormal returns than fund managers of funds with high IIR.

To address these concerns, I first augment the common four- and five-factor models with a new factor that captures the cross-section of expected stock returns linked to the nature of the firm. Every month, I compute the return on a factor mimicking Intangibles-Minus-Tangibles (IMT) portfolio that goes long High-R\&D stocks and short No-R\&D stocks. ${ }^{15}$ The IMT factor can be viewed as an omitted risk factor (see Chambers, Jennings, and Thompson (2002)), or a mispricing factor capturing systematic misvaluation of intangibles-intensive versus physical assets-intensive firms. The interpretation of IMT is not of particular importance in this study, since it is meant simply to account for systematic factors linked inherently to IIR that also predict stock returns. The goal is to incorporate $I M T$ as a factor into the model generating a fund's abnormal return, so that the loading and premium on IMT captures the proportion of mean return attributable to the passive strategy of going long HighR\&D stocks and short No-R\&D stocks. A fund's loading on IMT should increase with its IIR.

Figure 2 plots the mean equal-weighted monthly return on the IMT portfolio in each year. Consistent with existing studies, high R\&D-to-PPE firms tend to earn higher stock returns than NoR\&D firms. The IMT portfolio earns a substantial $1.63 \%$ per month on average. This is the first indication that augmenting factor models with IMT should, in fact, increase the spread in abnormal returns between funds with low IIR and funds with high IIR rather than "explain" this return spread.

\footnotetext{
${ }^{15}$ For the IMT portfolio, at the end of each year, the R\&D-to-PPE ratios for eligible stocks are computed where eligible stocks are selected following Pastor and Stambaugh (2003). The stocks are then sorted into 11 portfolios: Portfolio 0 with zero R\&D-to-PPE stocks ("No-R\&D stocks"), and 10 equal-sized portfolios with non-zero R\&D-to-PPE ranging from Portfolio 1 ("Low-R\&D stocks") to 10 ("High-R\&D stocks"). The return on the IMT portfolio is the return on the equalweighted Portfolio 10 minus Portfolio 0. The subsequent results are robust to alternative specifications of the IMT portfolio, including value-weighting the portfolios.
} 
Table 5 reports the abnormal returns obtained from adjustments for omitted factors linked to the nature of the firm. Column (1) reports the mean loadings on $I M T\left(\delta_{p}^{I M T}\right)$ for IIR decile portfolios

for the augmented five-factor model with $I M T$ as a sixth regressor. As expected, the lower (higher) IIR deciles load negatively (positively) on IMT. Moreover, the main results hold, with the Decile 1-10 alphas exceeding $6.54 \%$ per year for the augmented four- and five-factor models. In sum, controlling for omitted factors in the pricing of firms that vary in R\&D-to-PPE increases, rather than explains, the underperformance of high IIR funds relative to low IIR funds. In columns (4) and (5) of Table 5, I also include Hirshleifer and Jiang's (2010) Underpriced-Minus-Overpriced (UMO) factor to account for potential systematic mispricing of the style of stocks held. Consistent with earlier results, the IIR Decile 1-10 alphas remain significantly positive.

\section{Performance Decomposition: Fund Manager Skill, Fees, and Transaction Costs}

In earlier sections, the results reported were based on net returns which are a function of fund managers' skill as well as fees and transaction costs, and measure the returns passed on to investors. This section examines the relation between IIR and the components of fund performance, among which before-cost returns reflect the value added by managers using their selection and timing skills.

Table 6 reports the components of fund returns for the IIR decile portfolios using the performance decomposition approach of DGTW (1997) and Wermers (2000) who decompose returns into the fund manager's stock selection, style selection, timing ability, fees, and transaction costs. The following six components of returns are analyzed: Gross Holdings Return (i.e. holdings' buy-and-hold stock return), Characteristic Selectivity (CS), Characteristic Timing (CT), Average Style (AS), annual expenses (Expense Ratio), and Turnover Ratio capturing transaction costs. The measures are further described in Wermers (2000). By splitting each fund's portfolio into stocks with below mean (Low R\&D/PPE) and above mean (High R\&D/PPE) R\&D-to-PPE ratios in the quarter, Table 6 also reports 
the Gross Holdings Return and CS of the subportfolios of stocks with low R\&D-to-PPE and high R\&D-to-PPE separately. ${ }^{16}$ Table 6 shows that funds with high IIR charge higher fees and incur more transaction costs than funds with low IIR to at least partially explain their after-cost underperformance. However, the funds with high IIR also show significantly poorer before-cost stock selection skills relative to funds with low IIR. In columns (1) and (3), the funds in IIR Decile 1 pick stocks that outperform the stocks picked by funds in IIR Decile 10 by 314 (213) basis points per year based on gross returns $(C S)$. Interestingly, the high IIR funds underperform low IIR funds in physical assetsintensive holdings (columns (2), (5)) as well as intangibles-intensive holdings (columns (3), (6)). The disparity in the performance of the majority holdings of funds focused on physical assets-intensive firms versus those focused on intangibles-intensive firms is notable. The Low R\&D/PPE portfolio of IIR Decile 1 funds outperforms the High R\&D/PPE portfolio of IIR Decile 10 funds by a CS of $3.95 \%$. The Decile 1-10 difference in $A S$ of $1.39 \%$ is also positive and statistically significant. Finally, the IIR Decile 10 funds on average have expense ratios that are 18 basis points and turnovers that are nearly $43 \%$ higher on an annual basis than IIR Decile 1 funds. The funds with high IIR exhibit the "anomaly" of inferior before-fee performers charging higher expense ratios documented by Gruber (1996) and Gil-Bazo and Ruiz-Verdu (2009), among others.

\section{E. Additional Robustness Checks}

This section reports robustness tests that assess alternative explanations for the main results.

\section{E.1. Does IIR Proxy for Past (Intangible or Total) Stock Returns?}

Given the evidence in Daniel and Titman (2006) and Jiang (2010), if the IIR measure overweights innovative firms with high recent intangible returns, the main results may be explained by IIR proxying

\footnotetext{
${ }^{16}$ The sample of funds is restricted to those which have Low R\&D/PPE as well as High R\&D/PPE subportfolios.
} 
for stocks that are more likely to experience reversals of the intangible component of returns. This would make the interpretation based on fund managers' skill in valuing intangibles less clear.

Table 7 reports fund performance in settings that control for past stock returns. In Table 7 Panel A, funds are sorted into quartiles based on the funds' value-weighted intangible stock returns $\begin{aligned} & \text { Table } 7 \\ & \text { here }\end{aligned}$ over the one-year window, and (independently) into quintiles based on IIR. The funds with high IIR continue to underperform the funds with low IIR within groups of funds with similar exposure to intangible stock returns. The results in Panel B based on a five-year window are similar.

The setting in Table 7 Panel C controls for past total (instead of intangible) stock returns. To separate out the impact of recent price run-ups that may proxy for mispricing, I compute IIR at the end of quarter $t$ from portfolio weights that use lagged stock prices instead of end-of-quarter prices. I report returns in quarter $t+2$ for funds sorted into IIR quintiles, where the IIR uses stock prices lagged by one to four quarters. The results remain very robust, thereby ruling out patterns in recent stock returns as an explanation for the negative relation between $I I R$ and future fund returns.

\section{E.2. Long-term Fund Performance}

Another possibility that has not been considered so far is that funds with higher IIR benefit from market corrections of underpriced stocks over longer horizons. Table 8 addresses this issue by using decile ranks based on longer lags in IIR. Table 8 reports four-factor alphas for the IIR decile portfolios with IIR measured from holdings lagged by up to 12 quarters, reported in two-quarter increments. The here Decile 1-10 return spread remains statistically and economically meaningful till ten quarters following the measurement of IIR. Thus, IIR predicts long-term fund performance.

\section{E.3. Fund Attributes}

The existing literature suggests that certain fund attributes affect fund performance, and perhaps the relation between IIR and fund returns (e.g. fund size in Berk and Green (2004)). I perform robustness 
checks to see whether the main results hold across funds which vary in their attributes by doublesorting based on IIR and various fund attributes. The main results hold across the subsamples of funds which vary in their attributes (e.g. size and activeness). Due to space considerations, these results are reported in Table A1 in the Online Appendix.

\section{E.4. Alternative Measures of Intangibles}

Apart from innovative assets, a firm's value may also be driven by intangibles captured by advertising expenses or other non-innovative intangibles (e.g. copyrights). Further, the investors' ability to value intangibles may depend on the category of intangibles. Table 9 reports four-factor alphas for decile portfolios of funds formed based on the portfolio concentration in intangibles, measured as the fraction

of a fund's portfolio invested in stocks of firms that spend on R\&D in column (1), and the valueweighted ratio of $R \& D$ expenses to various base variables in columns (2)-(4). ${ }^{17}$ In column (5), R\&D Capital is scaled by total assets; ${ }^{18}$ in column (6), annual R\&D expense increases is scaled by lagged sales. Column (7) uses a widely used measure of innovative output, i.e. patents granted. Column (8) sorts funds on the value-weighted PPE intensity. Finally, columns (9) and (10) present results based on other categories of intangibles (scaled by PPE) that include non-innovative assets, namely, advertising and total intangible assets (COMPUSTAT Items 45, 33). The results based on innovative assets (columns (1)-(7)) are qualitatively very similar to those reported earlier. The Decile 1-10 alpha in column (8) is also consistent with other findings, since funds focused on firms with low PPE intensity underperform those focused on firms with high PPE intensity. Interestingly, returns do not

\footnotetext{
${ }^{17}$ Market value of equity is computed following Chan, Lakonishok, and Sougiannis (2001).

${ }^{18}$ Following Chan, Lakonishok, and Souginannis (2001), the R\&D Capital for firm $s$ at the end of year $t$ in which annual $\mathrm{R} \& \mathrm{D}$ expenses are denoted by $R D_{s, t}$ is computed as
}

$$
(\mathrm{R} \& \mathrm{D} \text { Capital })_{s, t}=R D_{s, t}+0.8 R D_{s, t-1}+0.6 R D_{s, t-2}+0.4 R D_{s, t-3}+0.2 R D_{s, t-4}
$$


vary significantly between funds which vary in their exposure to intangibles-intensive firms based on advertising expenses and total (accounting-based) intangible assets. These findings suggest that fund managers perform poorly when they focus on firms valued on innovative assets, while non-innovative intangibles do not appear to have a significant effect on abnormal returns. Perhaps the long-term value of innovative assets is particularly hard to assess due to their uniqueness to the firm (Aboody and Lev (2000)), while other intangible inputs (e.g. advertising) may share more commonalities across firms.

\section{E.5. Other Robustness Checks}

Additional tests summarized in Table A2 in the Online Appendix show that the results are not driven by the Dotcom bubble and bust period (1997-2002) since they hold in the 1980-1996, 1997-2002, as well as 2003-2009 periods. The results are also robust to the skewness in returns, TNA-weighting the alphas, exclusion of technology stocks in computing $I I R$, excluding funds with extreme TNA and risk factor loadings, and do not simply mirror compositional effects related to fund objectives.

\section{F. Valuation Difficulty versus the Nature of the Firm}

Can the cross-sectional differences in fund performance across funds which vary in their IIR be attributed to the nature of the firm? In addition to the misvaluation of intangibles, studies in behavioral finance suggest alternative channels via which forecasting errors could enter fund managers' valuation of firms. For instance, when the information is sparse, and valuation uncertainty and information asymmetry is high, behavioral biases lead to magnified forecasting errors (DHS $(1998,2001)$ ).

This section presents parsimonious tests that separate the effect of general information problems from the effect of the nature of the firm. Controlling for information problems like valuation uncertainty, if the performance of funds with high IIR is similar to those with low IIR, the results reported in earlier sections are most likely driven by forecasting errors linked to general valuation difficulties rather than the nature of the firm. For these tests, based on previous studies, I first select 
the following asset characteristics that proxy for a firm's information environment: firm size, firm age, book-to-market $(\mathrm{B} / \mathrm{M})$ ratio, and volume turnover. ${ }^{19}$ While each of these stock or firm attributes may reflect other non-informational factors (e.g. liquidity), they share the theme of proxying for the difficulty in firm valuation. Based on aggregating these asset characteristics on a value-weighted basis, I develop fund level measures of what I call the "proxies for valuation difficulty" (VD).

Table 10 reports four-factor alphas for portfolios formed by double-sorting funds on VD and IIR. Three portfolios of funds (Low 25\%, Medium 50\%, and High 25\%) are formed in each quarter Insert Table 11 including funds which have a VD ranked in the lowest $25 \%$, middle $50 \%$, and highest $25 \%$. Within each group, funds are then sorted into quintiles on IIR. The disparity in the risk-adjusted return of small cap funds (i.e. Low 25\% or High VD group based on Size Score) across IIR quintiles is striking. Small cap funds in IIR Quintile 1 (Quintile 5) produce an alpha of 3.01\% (-2.42\%). The IIR Quintile 1-5 alpha for these funds is a large 5.43\% per year. Taken with the evidence in Schultz (2010) that funds focused on difficult-to-value small firms outperform, it appears that fund managers display significant skill when they focus on stocks with low information availability and high information asymmetry, except when they invest in intangibles-intensive innovative segments. ${ }^{20}$ This is in spite of the fact that, controlling for firm size, firms having intangible assets are actually linked to more analyst

\footnotetext{
${ }^{19}$ Small cap stocks have more information uncertainty and lower information availability due to less analyst following (Zhang (2006), Hong, Lim, and Stein (2000)). Young firms with shorter histories have more information uncertainty and less publicly available information compared to older firms. Glamour (i.e. low B/M) stocks are valued based mainly on intangible information regarding future growth prospects, where investors find intangible information difficult to process (DHS (2001), Lakonishok, Shleifer, and Vishny (1994)). Volume turnover measured for a stock as the ratio of the monthly trading volume to the shares outstanding proxies for the ambiguity in the stock's true value (Kumar (2009)).

${ }^{20}$ Consistent with Schultz (2010), who uses gross returns, the four-factor alphas from net returns reveal the outperformance of small cap funds on average. The Low $25 \%$ Size Score funds have an overall mean alpha of $2.73 \%$ per year.
} 
following and effort than traditional firms (Barth, Kasznik, and McNichols (2001)). For the Medium 50\% and High 25\% Size Score groups, the IIR Quintile 1-5 alphas remain positive and significant. The results based on firm age, book-to-market ratio, and trading volume are similar. In general, the significantly positive (negative) alphas of larger magnitude are generated by funds focused on difficult-to-value firms in the lower (higher) IIR quintiles.

Overall, the results are consistent with the fund managers' forecasting errors in valuation being associated with the nature of the firm, and not by firms' information problems per se. ${ }^{21}$ In fact, fund managers exhibit significant skill when they focus on difficult-to-value firms in physical assetsintensive segments. It is plausible that learning from past experience and data equip fund managers' valuation techniques to handle information difficulties in traditional firms, hence turning mispricing into attractive opportunities, while the techniques for intangibles-intensive firms remain flawed. ${ }^{22}$

\section{G. Multivariate Regressions Explaining Fund Performance}

The results reported earlier in nonparametric settings show that fund managers outperform (underperform) when their portfolios are concentrated in physical assets-intensive (intangiblesintensive) firms. Moreover, Table 2 showed a positive relation between a fund's trend-chasing tendency and investments in intangibles-intensive firms, alluding to forecasting errors arising from extrapolation bias in valuing intangibles as a potential source of the underperformance of funds with high IIR. If this trend-chasing tendency does indeed represent extrapolation bias for funds with high $I I R$, it should be detrimental for fund performance. Also, since prior studies suggest that forecasting

\footnotetext{
${ }^{21}$ Note that the analyses do not test for specific types of forecasting errors (e.g. errors due to overconfidence versus limited attention) since the main goal is to examine general forecasting errors, irrespective of mechanism.

${ }^{22}$ This notion is consistent with the data since the value-weighted firm age of the firms in which funds with low IIR invest is twice that of the age of the firms in which funds with high $I I R$ invest.
} 
errors and behavioral biases like extrapolation bias decrease with learning, prior experience of fund managers could serve to reduce any such biases that affect their valuation of intangibles. With these possibilities in mind, this section analyzes fund performance in a multivariate setting with a twofold purpose: to examine the robustness of the link between $I I R$ and fund returns in a parametric setting, and to explore whether extrapolation bias and learning are among the channels via which the nature of the firm affects fund performance.

In addition to the mean returns, I examine two other attributes of fund returns that could be pertinent to mutual fund investors during the selection of funds, i.e. volatility and maximum payoffs. Portfolio theory proposes that traditional investors maximize expected returns and minimize the volatility of returns. Given the higher volatility of R\&D stocks (see Chan, Lakonishok, and Sougiannis (2001)), the volatility of fund returns likely increases with IIR, thereby proposing another channel via which IIR may affect the welfare of fund investors. Also, given the skewness of innovative assets' returns, investors may care about the potentially higher skewness of funds with higher $I I R^{23}$

Table 11 presents the results of regressions explaining fund level excess returns, four-factor alphas, volatility of excess returns (Volatility), and maximum excess returns (Maximum Return). A monthly excess returns and maximum monthly excess returns over the next 12 months $t+1$ to $t+12$. All specifications include year fixed effects. The significant negative relation between IIR and fund performance (i.e. excess return and four-factor alpha) in specifications that control for fund fixed

${ }^{23}$ Recent papers have shown that some stock market investors prefer assets with positive skewness in returns, in spite of their potentially negative expected returns (e.g. Barberis and Huang (2008), Bali, Cakici, and Whitelaw (2011)). For studies documenting the skewness of innovative asset returns, see Scherer and Harhoff (2000), Hall, Jaffe, and Trajtenberg (2005), and Silverberg and Verspagen (2007). Anecdotal evidence also points to high skewness in the returns on innovative assets like patents. For example, Pfizer's Lipitor patent generated sales of more than \$12.2 billion in 2005. 
effects lends further support to the preferred explanation of the main results in this study, i.e. that fund managers exhibit more skill when they focus on physical assets-intensive firms than when they focus on intangibles-intensive firms, since the fixed effects largely subsume any fund-, manager-, and family-level heterogeneities in skill and performance.

Several interesting results emerge when variables representing trend-chasing behavior and prior experience are incorporated in columns (2) and (5). Firstly, the significantly negative coefficient on MOM Score x IIR shows that the return of funds which exhibit trend-chasing behavior significantly decreases with their IIR. These findings point to the trend-chasing behavior representing extrapolation bias (versus rational momentum strategies) for funds with higher IIR. Secondly, consistent with fund managers learning about valuing intangibles with experience, the negative impact of IIR on returns significantly reduces with past experience. The results are similar where fund fixed effects are replaced with objective fixed effects and various untabulated fund level control variables.

Additionally, columns (7)-(12) in Table 11 show that volatility and maximum returns significantly increase with IIR. Taken together with earlier results on fund returns, it is evident that the mean-variance efficiency of a fund's portfolio decreases, and the maximum payoff increases with the fund's IIR. Further, the results in columns (7)-(12) suggest that trend-chasing behavior increases the volatility and maximum payoff of funds to a larger extent for funds with higher IIR, and past experience reduces the positive impact of $I I R$ on volatility and maximum payoff.

\section{Summary and Conclusions}

Using the portfolio holdings of actively managed U.S. mutual funds, this paper uncovers a significant link between the value created by fund managers' skill and the nature of the firms they invest in. Firstly, fund managers exhibit significantly inferior (superior) skill in generating risk-adjusted returns when their portfolios are tilted towards stocks of intangibles-intensive (physical assets-intensive) firms. 
The results are stronger when the factor models are adjusted for potential omitted systematic factors associated with the nature of the firm. Funds tilted towards intangibles-intensive firms underperform those tilted towards physical assets-intensive firms in the intangibles-intensive as well as physical assets-intensive components of their portfolios. Secondly, mutual fund managers tend to exhibit skill when they focus on difficult-to-value firms, except when the difficult-to-value firms are valued based on intangibles. Thirdly, there is evidence that funds' extrapolation bias increase with their focus on intangibles-intensive firms and this bias is detrimental to performance. In line with the presence of learning, the extrapolation bias and the negative impact of investments in intangibles-intensive firms on returns decreases with funds' prior experience. Finally, the nature of the firm affects the welfare of fund investors via multiple channels since the maximum payoff and volatility increases, and the meanvariance efficiency decreases, with the funds' exposure to intangibles-intensive firms.

The findings in this study raise several issues that may be promising avenues for future research. Although this paper clearly suggests that mutual funds tilted towards intangibles-intensive firms have inferior mean-variance properties but higher maximum payoffs than those tilted towards physical assets-intensive firms, it does not test whether fund investors account for how the properties of fund returns satisfy their preferences. Such clientele effects could be a critical factor in the survival of poor performers. Also, this study calls attention to the possibility that active management may not justify its costs in some market segments that seem to offer ample opportunities for exploiting market inefficiencies (e.g. innovative firms). Further research along these lines could lend fresh perspectives to comparisons between passive and active portfolio management. 


\section{References}

Aboody, D., and B. Lev. “Information Asymmetry, R\&D, and Insider Gains.” Journal of Finance, 55 (2000), 2747-2766.

Bali, T. G.; N. Cakici; and R. F. Whitelaw. "Maxing Out: Stocks as Lotteries and the Cross-Section of Expected Returns." Journal of Financial Economics, 99 (2011), 427-446.

Barberis, N., and M. Huang. "Stocks as Lotteries: The Implications of Probability Weighting for Security Prices." American Economic Review, 98 (2008), 2066-2100.

Barth, M.; R. Kasznik; and M. McNichols. "Analyst Coverage and Intangible Assets.” Journal of Accounting Research, 39 (2001), 1-34.

Berk, J. B., and R. C. Green. "Mutual Fund Flows and Performance in Rational Markets.” Journal of Political Economy, 112 (2004), 1269-1295.

Berk, J. B.; R. C. Green; and V. Naik. "Valuation and Return Dynamics of New Ventures.” Review of Financial Studies, 17 (2004), 1-35.

Bollen, N., and J. Busse. "Short-Term Persistence in Mutual Fund Performance." Review of Financial Studies, 18 (2004), 569-597.

Brown, S. J., and W. N. Goetzmann. “Performance Persistence.” Journal of Finance, 50 (1995), 679-698.

Brown, J. R.; S. M. Fazzari; and B. C. Petersen. "Financing Innovation and Growth: Cash Flow, External Equity, and the 1990s R\&D Boom.” Journal of Finance, 64 (2009), 151-185.

Carhart, M. “On Persistence in Mutual Fund Performance.” Journal of Finance, 52 (1997), 57-82.

Chambers, D. J.; R. Jennings; and R. B. Thompson. "Excess Returns to R\&D-Intensive Firms." Review of Accounting Studies, 7 (2002), 133-158.

Chan, L. K. C.; J. Lakonishok; and T. Sougiannis. "The Stock Market Valuation of Research and Development Expenditures." Journal of Finance, 56 (2001), 2431-2457.

Cohen, L.; K. Diether; and C. Malloy. "Misvaluing Innovation.” Unpublished working paper (2012), Harvard University, and Dartmouth University.

Core, J. E.; W. R. Guay; and A. V. Buskirk. "Market Valuations in the New Economy: An Investigation of What Has Changed." Journal of Accounting and Economics, 34 (2003), $43-67$.

Cremers, M., and A. Petajisto. "How Active is Your Fund Manager? A New Measure that Predicts Performance." Review of Financial Studies, 22 (2009), 3329-3365.

Daniel, K.; M. Grinblatt; S. Titman; and R. Wermers. "Measuring Mutual Fund Performance with Characteristic-Based 
Benchmarks.” Journal of Finance, 52 (1997), 1035-1058.

Daniel, K.; D. Hirshleifer; and A. Subrahmanyam. "Investor Psychology and Security Market Under- and Overreactions." Journal of Finance, 53 (1998), 1839-1886.

Daniel, K.; D. Hirshleifer; and A. Subrahmanyam. "Overconfidence, Arbitrage, and Equilibrium Asset Pricing.” Journal of Finance, 56 (2001), 921-965.

Daniel, K., and S. Titman. "Market's Reactions to Tangible and Intangible Information.” Journal of Finance, 61 (2006), $1605-1643$.

Eberhart, A.; W. F. Maxwell; and A. R. Siddique. “An Examination of Long-Term Abnormal Stock Returns and Operating Performance Following R\&D Increases.” Journal of Finance, 59 (2004), 623-651.

Edmans, A. "Does the Stock Market Fully Value Intangibles? Employee Satisfaction and Equity Prices.” Journal of Financial Economics, 101 (2011), 621-640.

Einhorn, H. J. “Overconfidence in Judgment.” New Directions for Methodology of Social and Behavioral Science 4 (1980), $1-16$.

Fama, E. F., and K. R. French. “Common Risk Factors in the Return on Bonds and Stocks.” Journal of Financial Economics, 33 (1993), 3-53.

Fama, E. F., and K. R. French. "Luck versus Skill in the Cross-section of Mutual Fund Returns." Journal of Finance, 65 (2010), 1915-1947.

Fama, E. F., and J. D. MacBeth. "Risk, Return, and Equilibrium: Empirical Tests." Journal of Political Economy, 81 (1973), $607-636$.

Frazzini, A. "The Disposition Effect and Under-Reaction to News.” Journal of Finance, 61 (2006), 2017-2046.

Gil-Bazo, J., and P. Ruiz-Verdu. "The Relation between Price and Performance in the Mutual Fund Industry." Journal of Finance, 64 (2009), 2153-2183.

Greenwood, R., and S. Nagel. “Inexperienced Investors and Bubbles.” Journal of Financial Economics, 93 (2009), $239-258$.

Griffin, D., and A. Tversky. "The Weighting of Evidence and the Determinants of Overconfidence.” Cognitive Psychology, 24 (1992), 411-435.

Grinblatt, M., and S. Titman. “The Persistence of Mutual Fund Performance.” Journal of Finance, 47 (1992), $1977-1984$.

Gruber, M. J. “Another Puzzle: The Growth in Actively Managed Mutual Funds.” Journal of Finance, 51 (1996), 783-810.

Hall, B.; A. Jaffe; and M. Trajtenberg. "Market Value and Patent Citations.” RAND Journal of Economics, 36 (2005), 16-38. Haruvy, E.; Y. Lahav; and C. Noussair. "Traders' Expectations in Asset Markets: Experimental Evidence.” American 
Economic Review, 97 (2007), 1901-1920.

Hirshleifer, D., and D. Jiang. “A Financing-based Misvaluation Factor and the Cross-Section of Expected Returns.” Review of Financial Studies, 23 (2010), 3401-3436.

Hirshleifer, D.; P. Hsu; and D. Li. "Innovative Efficiency and Stock Returns.” Journal of Financial Economics, forthcoming (2012).

Hong, H., and J. C. Stein. "A Unified Theory of Underreaction, Momentum Trading, and Overreaction in Asset Markets." Journal of Finance, 54 (1999), 2143-2184.

Hong, H.; T. Lim; and J. C. Stein. "Bad News Travels Slowly: Size, Analyst Coverage, and the Profitability of Momentum Strategies.” Journal of Finance, 55 (2000), 265-295.

Hong, H.; J. C. Stein; and J. Yu. "Simple Forecasts and Paradigm Shifts.” Journal of Finance, 62 (2007), 1207-1242.

Jensen, M. C. "The Performance of Mutual Funds in the Period 1945-1964." Journal of Finance, 23 (1968), 389-416.

Jensen, M. C. "The Modern Industrial Revolution, Exit, and the Failure of Internal Control Systems." Journal of Finance, 48 (1993), 831-880.

Jiang, H. "Institutional Investors, Intangible Information, and the Book-to-Market Effect." Journal of Financial Economics, 96 (2010), 98-126.

Kacperczyk, M.; C. Sialm; and L. Zheng. "On the Industry Concentration of Actively Managed Equity Mutual Funds.” Journal of Finance, 60 (2005), 1983-2011.

Kacperczyk, M.; C. Sialm; and L. Zheng. "Unobserved Actions of Equity Mutual Funds.” Review of Financial Studies, 21 (2008), 2379-2416.

Kosowski, R.; A. Timmermann; R. Wermers; and H. White. "Can Mutual Fund "Stars” Really Pick Stocks? New evidence from a Bootstrap Analysis.” Journal of Finance, 61 (2006), 2551-2595.

Kumar, A. "Hard-to-Value Stocks, Behavioral Biases, and Informed Trading." Journal of Financial and Quantitative Analysis, 44 (2009), 1375-1401.

Lakonishok, J.; A. Shleifer; and R. Vishny. "Contrarian Investment, Extrapolation, and Risk.” Journal of Finance, 49 (1994), $1541-1578$.

Newey, W. K., and K. D. West. “A Simple, Positive Semi-Definite, Heteroskedasticity and Autocorrelation Consistent Matrix Estimation.” Econometrica, 55 (1987), 703-708.

Pastor, L., and R. L. Stambaugh. "Liquidity Risk and Expected Stock Returns.” Journal of Political Economy, 111 (2003), 642-685. 
Rabin, M. "Inference by Believers in the Law of Small Numbers." Quarterly Journal of Economics, 117 (2002), 775-816.

Rajan, R. G., and L. Zingales. "The Governance of the New Corporation." Xavier Vives, ed. Corporate Governance Theoretical and Empirical Perspectives (2000), Cambridge: Cambridge University Press.

Rajan, R. G., and J. Wulf. “The Flattening Firm: Evidence from Panel Data on the Changing Nature of Corporate Hierarchies." Review of Economics and Statistics, 88 (2006), 759-773.

Scherer, F., and D. Harhoff. "Policy Implications for a World with Skew-Distributed Returns to Innovation.” Research Policy, 29 (2000), 559-566.

Schultz, P. H., "Rational Cross-Sectional Differences in Market Efficiency: Evidence from Mutual Funds.” Journal of Financial and Quantitative Analysis, 45 (2010), 847-881.

Seru, A.; T. Shumway; and N. Stoffman. "Learning by Trading.” Review of Financial Studies, 23 (2010), 705-739.

Silverberg, G., and B. Verspagen. “The Size Distribution of Innovations Revisited: An Application of Extreme Value Statistics to Citation and Value Measures of Patent Significance.” Journal of Econometrics, 139 (2007), 318-339

Wermers, R. "Mutual Fund Performance: An Empirical Decomposition into Stock-Picking Talent, Style, Transaction Costs, and Expenses." Journal of Finance, 55 (2000), 1655-1703.

Zhang, X. F. "Information Uncertainty and Stock Returns.” Journal of Finance, 61 (2006), 105-137.

Zingales, L. "In Search of New Foundations.” Journal of Finance, 55 (2000), 1623-1653. 
Figure 1

Mutual Funds' Portfolio Concentration in Intangibles

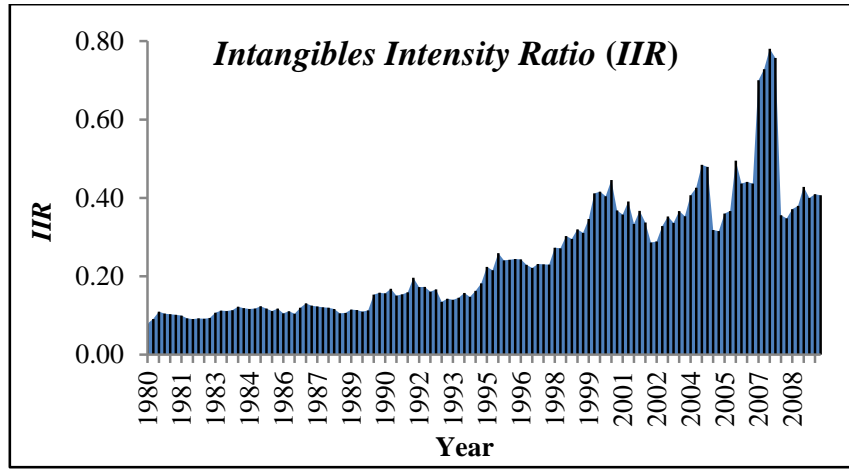

Graph A

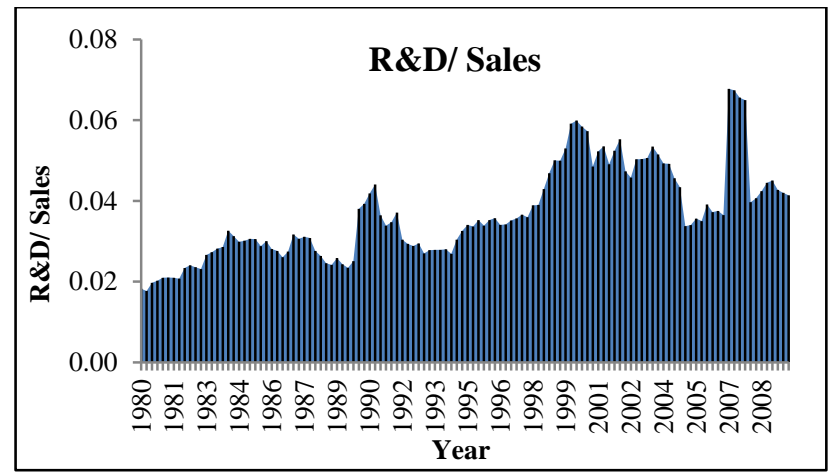

Graph B

Graph A presents the mean Intangibles Intensity Ratio (IIR) computed for each fund in each quarter as the value-weighted ratio of research and development (R\&D) expenses to property, plant, and equipment (PPE) expenses across all the firms in the portfolio. Graph B plots the R\&D-to-Sales ratio computed as the value-weighted ratio of $R \& D$ expenses to sales across all the firms in the portfolio.

Figure 2

Intangibles-Minus-Tangibles (IMT) Portfolio Return

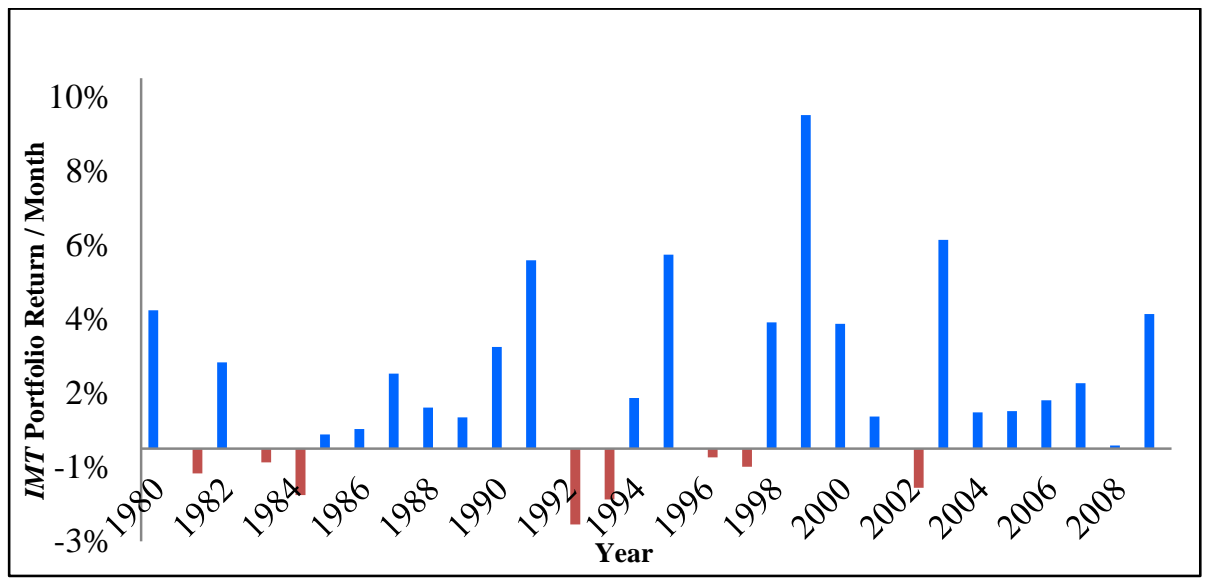

Figure 2 plots the average monthly equal-weighted return for the Intangibles-Minus-Tangibles (IMT) portfolio that goes long High-R\&D stocks and short No-R\&D stocks. High-R\&D stocks is the equalweighted portfolio of stocks ranked in the highest decile of R\&D-to-PPE in the most recent year. NoR\&D stocks is the equal-weighted portfolio of stocks with zero R\&D-to-PPE in the most recent year. 
Table 1

Descriptive Statistics on Mutual Funds' Portfolio Concentration in Intangibles

\begin{tabular}{|c|c|c|c|c|c|}
\hline & \multicolumn{5}{|c|}{ Panel A: All Objectives } \\
\hline & Overall & 1980-1989 & $1990-1995$ & $1996-2000$ & $2001-2009$ \\
\hline Intangibles Intensity Ratio (IIR) & 30.8 & 11.0 & 17.2 & 30.8 & 37.4 \\
\hline$\%$ R\&D stocks & 40.0 & 44.3 & 41.9 & 42.4 & 37.8 \\
\hline$R \& D / S a l e s$ & 4.3 & 2.7 & 3.2 & 4.6 & 4.7 \\
\hline R\&D/Book Equity & 7.4 & 5.3 & 6.3 & 9.3 & 7.2 \\
\hline R\&D/Assets & 3.3 & 2.7 & 3.0 & 4.0 & 3.1 \\
\hline R\&D Capital/Assets & 6.3 & 5.8 & 6.2 & 7.9 & 5.8 \\
\hline Advertising/PPE & 10.4 & 9.6 & 10.6 & 7.4 & 11.6 \\
\hline \multirow[t]{3}{*}{ Total Intangibles/PPE } & 140.9 & 15.0 & 45.4 & 77.4 & 208.4 \\
\hline & \multicolumn{5}{|c|}{ Panel B: Selected Objectives } \\
\hline & Overall & 1980-1989 & 1990-1995 & 1996-2000 & $2001-2009$ \\
\hline \multicolumn{6}{|l|}{ Aggressive Growth/Growth } \\
\hline Intangibles Intensity Ratio (IIR) & 32.9 & 12.0 & 20.2 & 34.0 & 39.9 \\
\hline$\%$ R\&D stocks & 42.1 & 43.7 & 42.7 & 45.0 & 40.6 \\
\hline $\mathrm{R} \& \mathrm{D} / \mathrm{Sales}$ & 5.0 & 2.8 & 3.8 & 5.4 & 5.5 \\
\hline \multicolumn{6}{|l|}{ Growth \& Income } \\
\hline Intangibles Intensity Ratio (IIR) & 17.1 & 8.1 & 8.9 & 17.5 & 21.7 \\
\hline$\%$ R\&D stocks & 40.5 & 46.8 & 44.3 & 45.4 & 35.3 \\
\hline $\mathrm{R} \& \mathrm{D} / \mathrm{Sales}$ & 3.3 & 2.3 & 2.4 & 3.6 & 3.7 \\
\hline \multicolumn{6}{|l|}{ Small Cap } \\
\hline Intangibles Intensity Ratio (IIR) & 50.4 & 14.3 & 29.3 & 42.7 & 55.0 \\
\hline$\%$ R\&D stocks & 35.8 & 38.7 & 35.5 & 33.9 & 36.2 \\
\hline R\&D/Sales & 4.4 & 2.7 & 3.6 & 4.4 & 4.5 \\
\hline \multicolumn{6}{|l|}{ Large Cap } \\
\hline$\overline{\text { Intangibles Intensity Ratio (IIR) }}$ & 26.0 & 9.7 & 12.2 & 24.9 & 31.4 \\
\hline$\%$ R\&D stocks & 43.5 & 46.5 & 45.3 & 49.7 & 41.0 \\
\hline$R \& D / S a l e s$ & 4.7 & 2.6 & 3.1 & 4.9 & 5.2 \\
\hline
\end{tabular}

The table reports descriptive statistics on the intangible assets of firms held by mutual funds during 1980 to 2009. Panel A and Panel B report statistics for the entire sample and for subsamples based on fund objectives, respectively. Mean values (in percentage) averaged across all funds are reported. Intangibles Intensity Ratio (IIR) of a fund is the value-weighted ratio of R\&D-to-PPE expenses across all the firms in the portfolio, weighted by the market value of holdings. \% R\&D stocks is the fraction of the portfolio invested in stocks of firms that spend on R\&D. Several alternative measures are computed as the value-weighted ratio of $R \& D$ expenses to the following base variables: sales (R\&D/Sales), book value of equity (R\&D/Book Equity), and total assets (R\&D/Assets, R\&D Capital/Assets). Advertising/PPE and Total Intangibles/PPE are the value-weighted ratios of advertising expenses and total intangible assets to PPE, respectively. All the measures are based on annual data for the firms from the most recent year before the portfolio quarter. 
Table 2

Multivariate Regressions Explaining Portfolio Concentration in Intangibles

\begin{tabular}{|c|c|c|c|c|c|c|}
\hline & \multicolumn{6}{|c|}{ Dependent variable: $I I R(t)$} \\
\hline & $(1)$ & (2) & (3) & (4) & $(5)$ & $(6)$ \\
\hline \multirow{2}{*}{$\overline{\text { Past IIR }}$} & $0.817^{* *}$ & $0.740^{* * *}$ & & $0.660^{* * *}$ & $0.649^{* *}$ & $0.645^{* *}$ \\
\hline & $(0.00)$ & $(0.00)$ & & $(0.00)$ & $(0.00)$ & $(0.00)$ \\
\hline \multirow[t]{2}{*}{ Size Score } & & & $-0.042^{* *}$ & $-0.017^{* * *}$ & $-0.017^{* *}$ & $-0.016^{* *}$ \\
\hline & & & $(0.00)$ & $(0.00)$ & $(0.00)$ & $(0.00)$ \\
\hline \multirow[t]{2}{*}{ Book-to-Market Score } & & & $-0.191^{* *}$ & $-0.074^{* * *}$ & $-0.077^{* *}$ & $-0.076^{* *}$ \\
\hline & & & $(0.00)$ & $(0.00)$ & $(0.00)$ & $(0.00)$ \\
\hline \multirow[t]{2}{*}{ MOM Score } & & & $0.059^{* *}$ & $0.032^{* *}$ & $0.028^{* *}$ & $0.027^{* *}$ \\
\hline & & & $(0.00)$ & $(0.00)$ & $(0.00)$ & $(0.00)$ \\
\hline \multirow[t]{2}{*}{ MOM Score x log (Fund Age) } & & & & $-0.006^{* *}$ & $-0.006^{* *}$ & $-0.006^{* *}$ \\
\hline & & & & $(0.00)$ & $(0.00)$ & $(0.00)$ \\
\hline \multirow[t]{2}{*}{ MOM Score x log (Manager Tenure) } & & & & $-0.003^{*}$ & -0.002 & -0.002 \\
\hline & & & & $(0.05)$ & $(0.20)$ & $(0.28)$ \\
\hline \multirow[t]{2}{*}{$\log ($ Fund Age) } & & & & $0.022^{* *}$ & $0.023^{* *}$ & $0.023^{* *}$ \\
\hline & & & & $(0.00)$ & $(0.00)$ & $(0.00)$ \\
\hline \multirow{2}{*}{$\log$ (Manager Tenure) } & & & & $-0.015^{* * *}$ & -0.009 & $-0.010^{*}$ \\
\hline & & & & $(0.00)$ & $(0.06)$ & $(0.04)$ \\
\hline \multirow[t]{2}{*}{ Expense Ratio } & & & & & 0.202 & 0.145 \\
\hline & & & & & $(0.44)$ & $(0.55)^{*}$ \\
\hline \multirow[t]{2}{*}{ Turnover Ratio } & & & & & $0.043^{* *}$ & $0.043^{\text {*** }}$ \\
\hline & & & & & $(0.00)$ & $(0.00)$ \\
\hline \multirow[t]{2}{*}{$\log (T N A)$} & & & & & $0.001^{*}$ & 0.001 \\
\hline & & & & & $(0.03)$ & $(0.09)$ \\
\hline \multirow[t]{2}{*}{ Past Flows } & & & & & $-0.107^{* *}$ & $-0.109^{* *}$ \\
\hline & & & & & $(0.01)$ & $(0.01)$ \\
\hline \multirow[t]{2}{*}{ Industry Concentration } & & & & & & $0.081^{* *}$ \\
\hline & & & & & & $(0.00)$ \\
\hline \multirow[t]{2}{*}{ Active Share } & & & & & & 0.006 \\
\hline & & & & & & $(0.32)$ \\
\hline Objective Fixed-effects & No & Yes & Yes & Yes & Yes & Yes \\
\hline Year Fixed-effects & No & Yes & Yes & Yes & Yes & Yes \\
\hline No. of observations & 96,303 & 96,303 & 93,433 & 70,589 & 70,589 & 70,589 \\
\hline R-squared & 0.492 & 0.540 & 0.364 & 0.556 & 0.558 & 0.560 \\
\hline
\end{tabular}

The table reports the results for regressions explaining the Intangibles Intensity Ratio (IIR) of actively managed mutual funds computed for each fund in each quarter $t$ during the period 1980 to 2009. IIR is as defined in Table 1. Past IIR is the fund's average $I I R$ in the four prior quarters $t-4$ to $t-1$. A fund's Size Score, Book-to-Market Score, and MOM Score are the value-weighted DGTW size quintile, DGTW book-to-market quintile, and DGTW momentum quintile in quarter $t$ - 1 , across all the stocks in the fund's portfolio in the quarter, respectively. log (Fund Age) and log (Manager Tenure) are the natural logarithms of the age (in years) of the fund computed from the first offer date, and number of years that the manager has managed the fund as of the end of quarter $t-1$ plus one, respectively. Expense Ratio and Turnover Ratio are annual values for the expense ratio and turnover of the fund in the prior year. $\log (T N A)$ is the natural logarithm of the fund's total net assets (\$mill) as of the end of 
quarter $t$-1. Past Flows is the mean monthly growth in TNA due to new money over the three months in quarter $t$-1. Industry Concentration is the fund's Herfindahl index across ten industry categories in the quarter $t$-1 (see Kacperczyk, Sialm, and Zheng (2005)), computed as the sum of squared weights in the ten industries. Active Share is defined as the share of a fund's portfolio holdings that differ from the fund's benchmark index (see Cremers and Petajisto (2009)) in the quarter $t$-1. The specifications in columns (2)-(6) include objective and year fixed effects. The $p$-values (in parentheses) are based on Newey-West robust standard errors with a lag length of three quarters, and account for clustering at the fund level. ${ }^{* *},{ }^{*}$ denote significance at the $1 \%$ and $5 \%$ level. 
Table 3

Factor Loadings and Persistence of Mutual Funds' Portfolio Concentration in Intangibles

\begin{tabular}{|c|c|c|c|c|c|c|c|c|c|c|c|}
\hline \multirow[b]{3}{*}{ IIR Decile $(t)$} & \multirow[b]{2}{*}{ Mean IIR } & \multicolumn{5}{|c|}{ Portfolio level factor loadings } & \multicolumn{5}{|c|}{$\%$ funds in $+/-1$ decile rank assigned at $t$ in quarter } \\
\hline & & $\beta_{p}^{M K T}$ & $\beta_{p}^{S M B}$ & $\beta_{p}^{H M L}$ & $\beta_{p}^{M O M}$ & $\beta_{p}^{L I Q}$ & $(t+1)$ & $(t+2)$ & $(t+3)$ & $(t+4)$ & $(t+5)$ \\
\hline & (1) & (2) & (3) & (4) & (5) & (6) & (7) & (8) & (9) & (10) & $(11)$ \\
\hline Decile 1 (Most Tangibles) & 0.033 & 0.850 & 0.283 & 0.189 & -0.016 & 0.018 & 96.8 & 95.1 & 93.9 & 93.2 & 93.2 \\
\hline Decile 2 & 0.075 & 0.895 & 0.270 & 0.136 & -0.025 & 0.012 & 94.7 & 92.8 & 91.6 & 91.4 & 90.9 \\
\hline Decile 3 & 0.106 & 0.900 & 0.247 & 0.068 & -0.018 & 0.003 & 91.9 & 88.2 & 86.5 & 86.1 & 86.3 \\
\hline Decile 4 & 0.136 & 0.912 & 0.235 & -0.017 & 0.001 & 0.008 & 88.8 & 84.4 & 82.5 & 83.0 & 83.7 \\
\hline Decile 5 & 0.163 & 0.916 & 0.206 & -0.086 & 0.008 & 0.004 & 87.7 & 83.5 & 82.0 & 82.3 & 82.8 \\
\hline Decile 6 & 0.191 & 0.926 & 0.251 & -0.158 & 0.001 & 0.011 & 87.1 & 82.2 & 81.1 & 81.0 & 81.4 \\
\hline Decile 7 & 0.230 & 0.943 & 0.285 & -0.237 & 0.016 & -0.012 & 88.6 & 83.8 & 82.4 & 82.5 & 83.0 \\
\hline Decile 8 & 0.286 & 0.963 & 0.378 & -0.306 & 0.034 & -0.012 & 90.8 & 87.0 & 85.4 & 84.5 & 84.8 \\
\hline Decile 9 & 0.393 & 0.977 & 0.524 & -0.451 & 0.041 & -0.029 & 93.5 & 90.7 & 89.5 & 88.5 & 88.5 \\
\hline Decile 10 (Most Intangibles) & 0.686 & 1.006 & 0.739 & -0.561 & 0.061 & -0.044 & 96.4 & 94.4 & 93.2 & 92.3 & 92.2 \\
\hline $\begin{array}{l}\text { Decile } 1-10 \\
(p \text {-value })\end{array}$ & $\begin{array}{l}-0.653^{* * *} \\
(0.00)\end{array}$ & $\begin{array}{c}-0.156^{* *} \\
(0.00)\end{array}$ & $\begin{array}{c}-0.456^{* * *} \\
(0.00)\end{array}$ & $\begin{array}{l}0.750^{* *} \\
(0.00)\end{array}$ & $\begin{array}{l}-0.077^{* *} \\
(0.00)\end{array}$ & $\begin{array}{l}0.062^{* *} \\
(0.00)\end{array}$ & & & & & \\
\hline
\end{tabular}

At the end of each quarter $t$, funds are sorted into decile portfolios based on their IIR as defined in Table 1. Column (1) reports the mean

$I I R$ of the funds in each decile portfolio in the ranking quarter $t$. Columns (2)-(6) report the time series mean of the factor loadings (betas) for each decile portfolio estimated from the following five-factor model

$$
r_{p, t}=\alpha_{p}+\beta_{p}^{M K T}\left(R M_{t}-R f_{t}\right)+\beta_{p}^{S M B} S M B_{t}+\beta_{p}^{H M L} H M L_{t}+\beta_{p}^{M O M} M O M_{t}+\beta_{p}^{L I Q} L I Q_{t}+\varepsilon_{p, t}
$$

$r_{p, t}$ is the excess return on the decile portfolio $p$ in month $t$, computed as the equal-weighted mean monthly excess net fund return. $R M_{t}$ $R f_{t}, S M B_{t}$, and $H M L_{t}$ are the three factors from Fama and French (1993), MOM ${ }_{t}$ is the momentum factor used in Carhart (1997), and $L I Q_{t}$ is the liquidity factor in Pastor and Stambaugh (2003). The factor loadings in month $t$ are obtained by regressing $r_{p, t}$ on the factor realizations over $t$-36 to $t-1$. The "\% funds in $+/-1$ decile rank assigned at $t$ in quarter" is the fraction of funds ranked in a decile in the ranking quarter $t$ that remain within one rank in five future quarters $t+1$ through $t+5$. The $p$-values in parentheses are based on NeweyWest standard errors (lag length 12 months). ${ }^{* *},{ }^{*}$ represent statistical significance at the $1 \%$ and $5 \%$ level. 
Table 4

Mutual Fund Performance and Portfolio Concentration in Intangibles

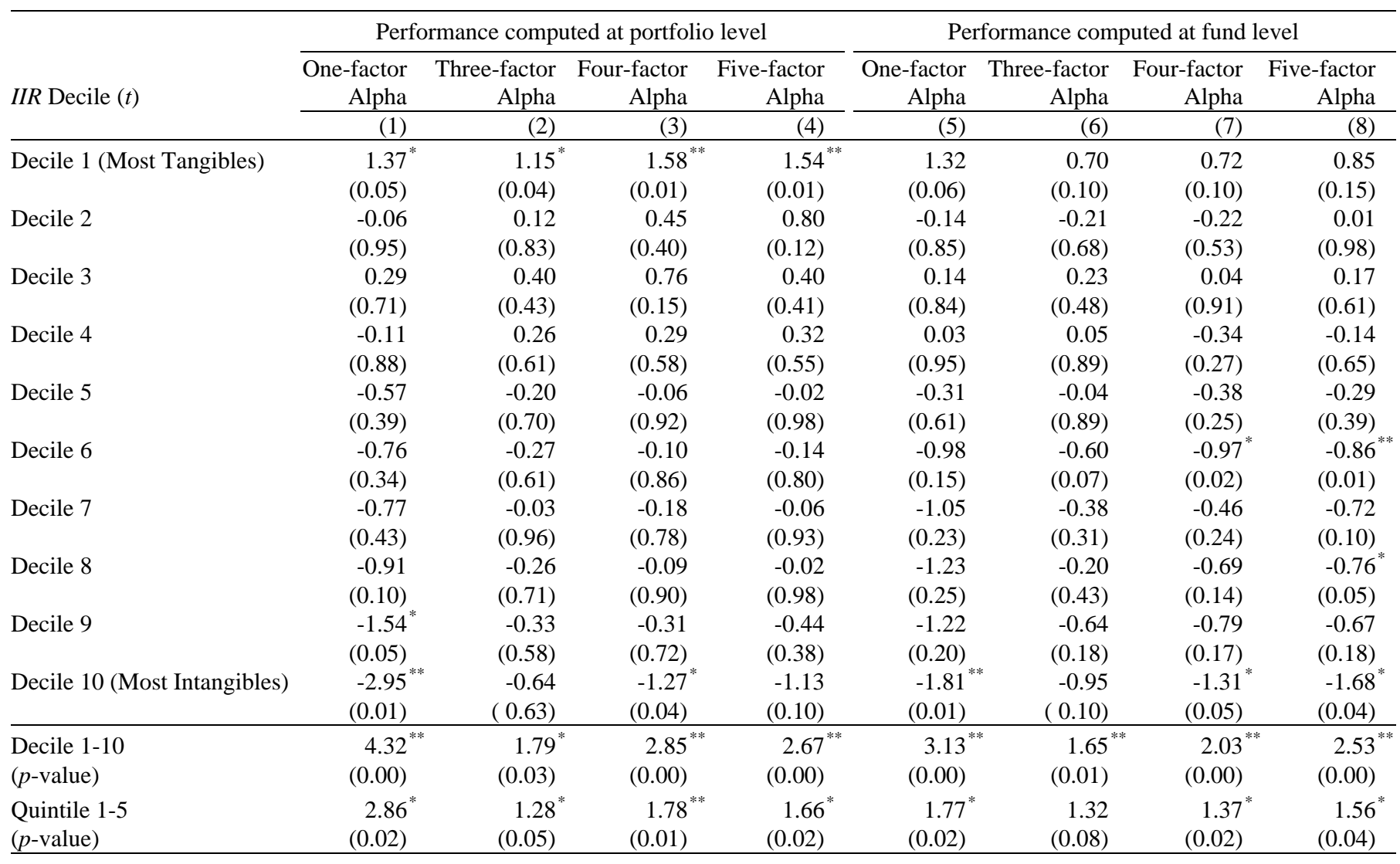

In columns (1)-(4), the table report the time series means of the portfolio level alphas over the three months in quarter $t+2$, computed in month $t$ as the excess return on the portfolio minus the product of the factor realizations in month $t$ and the portfolio's factor loadings estimated over the 36-month rolling window $t$-36 to $t$-1. One-, Three-, Four-, and Five-factor Alpha is obtained from the regression described in Table 3 using the first regressor (Jensen (1968)), the first three regressors (Fama and French (1993)), the first four regressors (Carhart (1997)), and all five regressors (Pastor and Stambaugh (2003)). Columns (5)(8) report the time series means of the fund level alphas over the three months in quarter $t+2$ computed following the rolling-regression method based on the time series of monthly excess return for individual funds. All returns are reported in percentage on a per year basis. The $p$-values based on Newey-West robust standard errors with a lag length of 12 months are reported in parentheses. ${ }^{* *},{ }^{*}$ represent statistical significance at the $1 \%$ and $5 \%$ level. 


\section{Table 5}

\section{Mutual Fund Performance Adjusted for Omitted Factors in Factor Adjustment Models}

\begin{tabular}{|c|c|c|c|c|c|}
\hline \multirow[t]{2}{*}{ IIR Decile $(t)$} & $\delta_{I M T}$ & $\begin{array}{r}\text { Four-factor w/ IMT } \\
\text { Alpha }\end{array}$ & $\begin{array}{r}\text { Five-factor w/ IMT } \\
\text { Alpha }\end{array}$ & $\begin{array}{r}\text { Five-factor w/ } U M O \\
\text { Alpha }\end{array}$ & $\begin{array}{r}\text { Five-factor w/ UMO, } \\
I M T \text { Alpha }\end{array}$ \\
\hline & (1) & (2) & (3) & (4) & (5) \\
\hline \multirow[t]{2}{*}{ Decile 1 (Most Tangibles) } & $-0.539^{* * *}$ & $2.57^{* *}$ & $2.63^{* *}$ & $1.82^{* *}$ & $2.93^{* *}$ \\
\hline & $(0.00)$ & $(0.00)$ & $(0.00)$ & $(0.01)$ & $(0.00)$ \\
\hline \multirow[t]{2}{*}{ Decile 2} & $-0.491^{* *}$ & $1.20^{*}$ & $1.20^{*}$ & 0.83 & $1.16^{*}$ \\
\hline & $(0.00)$ & $(0.03)$ & $(0.03)$ & $(0.12)$ & $(0.04)$ \\
\hline \multirow[t]{2}{*}{ Decile 3} & $-0.237^{* *}$ & $1.16^{*}$ & $1.27^{*}$ & 0.41 & $1.47^{* *}$ \\
\hline & $(0.00)$ & $(0.03)$ & $(0.02)$ & (0.43) & $(0.01)$ \\
\hline \multirow{2}{*}{ Decile 4} & $-0.235^{* *}$ & 0.70 & 0.74 & 0.38 & $1.03^{*}$ \\
\hline & $(0.00)$ & $(0.18)$ & $(0.17)$ & $(0.48)$ & $(0.05)$ \\
\hline \multirow[t]{2}{*}{ Decile 5} & $-0.105^{* *}$ & 0.22 & 0.27 & 0.66 & 0.85 \\
\hline & $(0.00)$ & $(0.70)$ & $(0.63)$ & $(0.29)$ & $(0.13)$ \\
\hline \multirow[t]{2}{*}{ Decile 6} & -0.021 & -0.13 & -0.17 & 0.23 & 0.34 \\
\hline & $(0.49)$ & $(0.82)$ & $(0.76)$ & $(0.67)$ & $(0.55)$ \\
\hline \multirow[t]{2}{*}{ Decile 7} & $0.105^{* *}$ & -0.35 & -0.21 & 0.27 & 0.75 \\
\hline & $(0.00)$ & $(0.58)$ & $(0.74)$ & $(0.64)$ & $(0.24)$ \\
\hline \multirow[t]{2}{*}{ Decile 8} & $0.317^{* *}$ & -0.50 & -0.43 & 0.18 & 0.81 \\
\hline & $(0.00)$ & $(0.48)$ & $(0.56)$ & $(0.80)$ & $(0.26)$ \\
\hline \multirow[t]{2}{*}{ Decile 9} & $0.541^{* *}$ & -1.43 & -1.28 & 0.05 & -0.11 \\
\hline & $(0.00)$ & $(0.10)$ & $(0.20)$ & $(0.97)$ & $(0.87)$ \\
\hline \multirow[t]{2}{*}{ Decile 10 (Most Intangibles } & $1.683^{* *}$ & $-3.97^{* *}$ & $-3.94^{* *}$ & -0.22 & -1.33 \\
\hline & $(0.00)$ & $(0.00)$ & $(0.00)$ & $(0.77)$ & $(0.08)$ \\
\hline \multirow{2}{*}{$\begin{array}{l}\text { Decile } 1-10 \\
(p \text {-value })\end{array}$} & $-2.222^{* * *}$ & $6.54^{*}$ & $6.57^{* *}$ & 2.04 ** & $4.26 *$ \\
\hline & $(0.00)$ & $(0.00)$ & $(0.00)$ & $(0.00)$ & $(0.00)$ \\
\hline \multirow{2}{*}{$\begin{array}{l}\text { Quintile 1-5 } \\
\text { (p-value) }\end{array}$} & $-1.605^{* *}$ & $4.56^{* * *}$ & $4.48^{* *}$ & $1.53^{*}$ & $2.10^{* *}$ \\
\hline & $(0.00)$ & $(0.00)$ & $(0.00)$ & $(0.05)$ & $(0.00)$ \\
\hline
\end{tabular}

The table reports the portfolio level alphas for portfolios formed in quarter $t$ over the three months in quarter $t+2$. The alphas are obtained from the regression of the monthly net excess return on decile portfolio $p$ in month $t\left(r_{p, t}\right)$ on all or some of the five factors defined in Table 3, in addition to an IMT and $U M O$ factor. $I M T$ is the Intangibles-Minus-Tangibles factor that is long on High-R\&D stocks and short on No-R\&D stocks, as defined in Figure 2. $U M O$ is the Underpricing-Minus-Overpricing misvaluation factor in Hirshleifer and Jiang (2010) that is long on underpriced and short on overpriced stocks. Four(Five-) factor w/ IMT Alpha is obtained from the above regression using the first four (five) regressors and $I M T_{t}$. Five-factor w/ UMO (w/ UMO, IMT) Alpha is obtained from the above regression using the first five regressors with $U M O(U M O$ and $I M T) . \quad \delta_{p}^{I M T}$ is the time series mean of the coefficient on $I M T_{t}$ obtained from the Five-factor w/ IMT specification. All returns are reported in percentage on a per year basis. The $p$-values based on Newey-West robust standard errors with a lag length of 12 months are reported in parentheses. ${ }^{* *},{ }^{*}$ represent statistical significance at the $1 \%$ and $5 \%$ level. 
Table 6

Return Decomposition for Mutual Funds and Portfolio Concentration in Intangibles

\begin{tabular}{|c|c|c|c|c|c|c|c|c|c|c|c|c|}
\hline \multirow{3}{*}{ IIR Decile $(t)$} & \multicolumn{4}{|c|}{ Gross Holdings Return } & \multicolumn{4}{|c|}{$C S$} & \multirow[b]{2}{*}{$C T$} & \multirow[b]{2}{*}{$A S$} & \multirow[b]{2}{*}{$\begin{array}{r}\text { Expense } \\
\text { Ratio }\end{array}$} & \multirow[b]{2}{*}{$\begin{array}{r}\text { Turnover } \\
\text { Ratio }\end{array}$} \\
\hline & All & $\begin{array}{r}\text { Low } \\
\text { R\&D/PPE } \\
\end{array}$ & $\begin{array}{r}\text { High } \\
\text { R\&D/PPE } \\
\end{array}$ & $\begin{array}{l}\text { Low-High } \\
\text { R\&D/PPE }\end{array}$ & All & $\begin{array}{r}\text { Low } \\
\text { R\&D/PPE } \\
\end{array}$ & $\begin{array}{r}\text { High } \\
\mathrm{R} \& \mathrm{D} / \mathrm{PPE} \\
\end{array}$ & $\begin{array}{l}\text { Low-High } \\
\text { R\&D/PPE }\end{array}$ & & & & \\
\hline & $(1)$ & $(2)$ & (3) & (4) & $(5)$ & $(6)$ & $(7)$ & $(8)$ & $(9)$ & (10) & $(11)$ & $(12)$ \\
\hline Decile 1 (Most Tangibles) & 14.70 & 14.75 & 13.87 & 0.88 & 1.28 & 1.33 & 0.50 & 0.83 & -0.01 & 13.43 & 1.16 & 70.28 \\
\hline Decile 2 & 13.52 & 13.53 & 13.47 & 0.06 & 1.25 & 1.26 & 1.11 & 0.15 & 0.06 & 12.22 & 1.13 & 71.67 \\
\hline Decile 3 & 14.14 & 16.32 & 13.87 & $2.45^{* *}$ & 1.79 & 1.94 & 0.54 & $1.40^{* *}$ & -0.08 & 12.43 & 1.08 & 71.20 \\
\hline Decile 4 & 13.49 & 15.02 & 13.26 & $1.76^{* *}$ & 1.77 & 1.97 & 0.42 & $1.55^{* *}$ & -0.16 & 11.88 & 1.09 & 75.49 \\
\hline Decile 5 & 12.92 & 14.85 & 12.61 & $2.24^{* *}$ & 1.72 & 1.91 & 0.54 & $1.37^{*}$ & -0.81 & 12.02 & 1.13 & 76.13 \\
\hline Decile 6 & 12.90 & 13.77 & 12.74 & $1.03^{*}$ & 1.02 & 1.11 & 0.57 & 0.54 & 0.21 & 11.67 & 1.11 & 80.20 \\
\hline Decile 7 & 12.47 & 12.33 & 13.08 & -0.75 & 0.45 & 0.45 & 0.44 & 0.01 & 0.54 & 11.48 & 1.14 & 88.95 \\
\hline Decile 8 & 12.79 & 12.73 & 13.01 & -0.28 & 0.55 & 0.45 & 0.91 & -0.46 & 0.22 & 12.02 & 1.12 & 93.06 \\
\hline Decile 9 & 11.80 & 12.27 & 10.32 & $1.95^{*}$ & 0.05 & 0.12 & -0.17 & 0.29 & 0.42 & 11.33 & 1.15 & 104.44 \\
\hline Decile 10 (Most Intangibles) & 11.55 & 13.19 & 8.28 & $4.91^{* *}$ & -0.85 & -0.01 & -2.62 & $2.61^{* *}$ & 0.36 & 12.04 & 1.34 & 113.20 \\
\hline $\begin{array}{l}\text { Decile 1-10 } \\
(p \text {-value) }\end{array}$ & $\begin{array}{c}3.14^{* *} \\
(0.00)\end{array}$ & $\begin{array}{c}1.56^{* *} \\
(0.00)\end{array}$ & $\begin{array}{c}5.59^{* *} \\
(0.00)\end{array}$ & & $\begin{array}{c}2.13^{\text {** }} \\
(0.00)\end{array}$ & $\begin{array}{c}1.34^{* *} \\
(0.00)\end{array}$ & $\begin{array}{c}3.12^{* * *} \\
(0.00)\end{array}$ & & $\begin{array}{l}-0.37 \\
(0.23)\end{array}$ & $\begin{array}{c}1.39^{*} \\
(0.04)\end{array}$ & $\begin{array}{l}-0.18^{* *} \\
(0.00)\end{array}$ & $\begin{array}{c}-42.92^{* * *} \\
(0.00)\end{array}$ \\
\hline $\begin{array}{l}\text { Quintile 1-5 } \\
(p \text {-value) }\end{array}$ & $\begin{array}{r}2.04^{* *} \\
(0.00) \\
\end{array}$ & $\begin{array}{c}1.43^{* *} \\
(0.01) \\
\end{array}$ & $\begin{array}{c}4.02^{* * *} \\
(0.00) \\
\end{array}$ & & $\begin{array}{r}1.35 \\
(0.06) \\
\end{array}$ & $\begin{array}{r}1.18 \\
(0.07) \\
\end{array}$ & $\begin{array}{r}1.72^{*} \\
(0.02) \\
\end{array}$ & & $\begin{array}{r}-0.09 \\
(0.88) \\
\end{array}$ & $\begin{array}{r}0.99 \\
(0.13) \\
\end{array}$ & $\begin{array}{c}-0.08^{*} \\
(0.04) \\
\end{array}$ & $\begin{array}{l}-39.23^{* * *} \\
(0.00) \\
\end{array}$ \\
\hline
\end{tabular}

The following components of fund returns are reported in the table: value-weighted return on the stock portfolio (Gross Holdings Return),

Characteristic Selectivity (CS), Characteristic Timing (CT), Average Style (AS), Expense Ratio, and Turnover Ratio. All and Low (High)

R\&D/PPE represent the fund's whole portfolio and subportfolio of stocks with below (above) mean values of R\&D/PPE in the quarter,

respectively. The components of fund returns are computed on a monthly basis and reported as percentage per year. The expense ratio and turnover are reported as annual percentage values. The components are reported for each decile portfolio as an equal-weighted average across all funds in the decile across all months. The $p$-values based on Newey-West robust standard errors with a lag length of 12 months are reported in parentheses. ${ }^{* *},{ }^{*}$ represent statistical significance at the $1 \%$ and $5 \%$ level, respectively. 


\section{Table 7}

\section{Past Stock Returns and Portfolio Concentration in Intangibles}

\begin{tabular}{|c|c|c|c|c|}
\hline \multirow[b]{2}{*}{ IIR Quintile $(t)$} & \multicolumn{4}{|c|}{ Panel A: Sorting on past intangible stock returns (One year) } \\
\hline & Quartile 1 & Quartile 2 & Quartile 3 & Quartile 4 \\
\hline Quintile 1 (Most & 0.80 & 0.89 & 0.61 & $1.79^{*}$ \\
\hline Quintile 2 & 0.39 & 0.23 & 0.46 & 0.96 \\
\hline Quintile 3 & 0.02 & -0.60 & -0.45 & -0.88 \\
\hline Quintile 4 & -0.01 & -0.59 & -0.48 & -0.74 \\
\hline Quintile 5 (Most & -0.19 & -0.63 & -1.08 & $-1.58^{*}$ \\
\hline \multirow[t]{2}{*}{$(p$-value $)$} & $\begin{array}{r}0.99 \\
(0.19) \\
\end{array}$ & $\begin{array}{r}1.52^{*} \\
(0.03)\end{array}$ & $\begin{array}{l}1.69^{* *} \\
(0.01)\end{array}$ & $\begin{array}{l}3.37^{* * *} \\
(0.00)\end{array}$ \\
\hline & \multicolumn{4}{|c|}{ Panel B: Sorting on past intangible stock returns (Five year) } \\
\hline IIR Quintile $(t)$ & Quartile 1 & Quartile 2 & Quartile 3 & Quartile 4 \\
\hline Quintile 1 (Most & 0.39 & $0.87^{*}$ & 0.70 & $1.24^{*}$ \\
\hline Quintile 2 & 0.40 & -0.21 & 0.17 & 0.75 \\
\hline Quintile 3 & -0.05 & -0.40 & -0.84 & -0.56 \\
\hline Quintile 4 & -0.19 & -0.21 & -0.68 & -0.91 \\
\hline Quintile 5 (Most & 0.09 & -0.70 & -1.33 & $-1.45^{*}$ \\
\hline \multirow[t]{2}{*}{$(p$-value $)$} & $\begin{array}{r}0.30 \\
(0.60) \\
\end{array}$ & $\begin{array}{r}1.57^{*} \\
(0.05)\end{array}$ & $\begin{array}{l}2.03^{* *} \\
(0.00)\end{array}$ & $\begin{array}{l}2.69^{* * *} \\
(0.00)\end{array}$ \\
\hline & \multicolumn{4}{|c|}{ Panel C: Portfolio weights from stock prices lagged by $m$ months } \\
\hline IIR Quintile $(t)$ & $m=3$ & $m=6$ & $m=9$ & $m=12$ \\
\hline Quintile 1 (Most & $1.81^{* * *}$ & $1.79^{* * *}$ & $1.60^{*}$ & $1.30^{*}$ \\
\hline Quintile 2 & 0.35 & 0.45 & 0.32 & 0.28 \\
\hline Quintile 3 & -0.24 & -0.26 & -0.29 & -0.40 \\
\hline Quintile 4 & -0.80 & -0.80 & -0.75 & -0.72 \\
\hline Quintile 5 (Most & $-1.21^{*}$ & -1.17 & -1.12 & $-1.20^{*}$ \\
\hline $\begin{array}{l}\text { Quintile 1-Quintile } 5 \\
\text { ( } p \text {-value) }\end{array}$ & $\begin{array}{l}3.02^{* *} \\
(0.00)\end{array}$ & $\begin{array}{l}2.96^{* * *} \\
(0.00)\end{array}$ & $\begin{array}{l}2.72^{* *} \\
(0.00)\end{array}$ & $\begin{array}{l}2.50^{* * *} \\
(0.01)\end{array}$ \\
\hline
\end{tabular}

Panel A and Panel B in the table report the portfolio level four-factor alphas from monthly net excess returns for portfolios formed by independently sorting funds into quintile portfolios based on $I I R$, and quartile portfolios based on the intangible returns on the stocks they hold. In Panel A (Panel B), the intangible returns on the stocks held by a fund is computed as the value-weighted intangible stock returns, where a stock's intangible return is computed in the most recent calendar year as the intangible component of the one-year (five-year) stock return. Panel C reports the portfolio level four-factor alphas from monthly net excess returns for quintile portfolios sorted based on IIR in quarter $t$, where the portfolio weights used to compute IIR are based on stock prices lagged by $m$ months from the last month of quarter $t$, where $m$ is $3,6,9$, or 12 months. The $p$-values based on Newey-West robust standard errors with a lag length of 12 months are reported in parentheses. ${ }^{* *},{ }^{*}$ represent statistical significance at the $1 \%$ and $5 \%$ level. 
Table 8

Long-term Performance and Portfolio Concentration in Intangibles

\begin{tabular}{lcrrrr}
\hline & \multicolumn{5}{c}{ Four-factor Alpha in quarter } \\
IIR Decile $(t)$ & $(t+4)$ & $(t+6)$ & $(t+8)$ & $(t+10)$ & $(t+12)$ \\
\cline { 2 - 6 } & $(1)$ & $(2)$ & $(3)$ & $(4)$ & $(5)$ \\
\hline \multirow{2}{*}{ Decile 1 (Most Tangibles) } & $1.42^{* *}$ & $1.21^{*}$ & $1.12^{*}$ & $1.08^{*}$ & 0.77 \\
& $(0.01)$ & $(0.04)$ & $(0.03)$ & $(0.04)$ & $(0.15)$ \\
Decile 2 & 0.63 & 0.63 & 0.67 & 0.73 & 1.00 \\
& $(0.25)$ & $(0.21)$ & $(0.21)$ & $(0.17)$ & $(0.08)$ \\
Decile 3 & 0.61 & 0.52 & 0.77 & 0.21 & 0.76 \\
& $(0.23)$ & $(0.34)$ & $(0.15)$ & $(0.71)$ & $(0.16)$ \\
Decile 4 & 0.27 & 0.71 & 0.85 & 0.60 & 0.02 \\
& $(0.61)$ & $(0.20)$ & $(0.13)$ & $(0.30)$ & $(0.98)$ \\
Decile 5 & -0.19 & 0.32 & 0.43 & 0.28 & 0.24 \\
Decile 6 & $(0.73)$ & $(0.55)$ & $(0.42)$ & $(0.61)$ & $(0.68)$ \\
& -0.02 & 0.26 & 0.07 & 0.03 & -0.07 \\
Decile 7 & $(0.98)$ & $(0.65)$ & $(0.90)$ & $(0.96)$ & $(0.90)$ \\
& 0.20 & 0.05 & 0.08 & 0.21 & 0.21 \\
Decile 8 & $(0.73)$ & $(0.93)$ & $(0.90)$ & $(0.74)$ & $(0.76)$ \\
& 0.04 & 0.02 & 0.16 & 0.10 & 0.50 \\
Decile 9 & $(0.95)$ & $(0.98)$ & $(0.82)$ & $(0.89)$ & $(0.49)$ \\
& -0.73 & 0.06 & -0.10 & -0.13 & -0.22 \\
Decile 10 (Most Intangibles) & $(0.14)$ & $(0.94)$ & $(0.91)$ & $(0.88)$ & $(0.76)$ \\
& -1.11 & -0.41 & -0.33 & -0.28 & -0.35 \\
Decile 1-Decile 10 & $(0.10)$ & $(0.73)$ & $(0.23)$ & $(0.49)$ & $(0.77)$ \\
\hline -value) & $2.53^{* *}$ & $1.62 * *$ & $1.45^{*}$ & 1.36 & 1.12 \\
& $(0.00)$ & $(0.01)$ & $(0.05)$ & $(0.07)$ & $(0.17)$ \\
& $1.70^{*}$ & 1.13 & 0.98 & 0.77 & 0.59 \\
& $(0.05)$ & $(0.09)$ & $(0.10)$ & $(0.21)$ & $(0.26)$ \\
\hline
\end{tabular}

The table reports the portfolio level four-factor alphas from monthly net excess returns for decile portfolios in quarters $(t+4),(t+6),(t+8),(t+10)$, and $(t+12)$ based on the rolling-regression method described in Table 4. The four benchmark factors used to compute alphas are $\left(R M_{t}-R f_{t}\right), S M B_{t}, H M L_{t}$, and $M O M_{t}$ and are as defined in Table 3. The $p$-values based on Newey-West robust standard errors with a lag length of 12 months are reported in parentheses. *** , represent statistical significance at the $1 \%$ and $5 \%$ level. 
Table 9

Portfolios of Mutual Funds Sorted on Alternative Measures of Portfolio Concentration in Intangibles

\begin{tabular}{|c|c|c|c|c|c|c|c|c|c|c|}
\hline & \multicolumn{10}{|c|}{ Firms' intangibles based on } \\
\hline & $\begin{array}{r}\% \mathrm{R} \& \mathrm{D} \\
\text { stocks }\end{array}$ & $\begin{array}{c}\text { R\&D } \\
\text { /Sales }\end{array}$ & $\begin{array}{r}\text { R\&D } \\
\text { /Book Equity }\end{array}$ & $\begin{array}{r}\mathrm{R} \& \mathrm{D} \\
\text { /Market Equity }\end{array}$ & $\begin{array}{r}\text { R\&D Capital } \\
\text { /Assets }\end{array}$ & $\begin{array}{r}\text { R\&D Increase } \\
\text { /Sales }\end{array}$ & $\begin{array}{l}\text { No. of } \\
\text { Patents }\end{array}$ & $\begin{array}{r}\text { PPE } \\
\text { /Assets }\end{array}$ & $\begin{array}{r}\text { Advertising } \\
\text { /PPE }\end{array}$ & $\begin{array}{r}\text { Total Intangibles } \\
\text { /PPE }\end{array}$ \\
\hline & $(1)$ & (2) & (3) & (4) & $(5)$ & (6) & $(7)$ & $(8)$ & (9) & $(10)$ \\
\hline \multirow[t]{2}{*}{ Decile 1 (Most Tangibles) } & $1.25^{*}$ & $1.76^{* *}$ & $1.95^{* *}$ & 0.67 & $1.62^{* *}$ & 1.21 & 0.62 & $-1.81^{* *}$ & 0.50 & -0.39 \\
\hline & $(0.04)$ & $(0.01)$ & $(0.00)$ & $(0.31)$ & $(0.00)$ & $(0.07)$ & $(0.32)$ & $(0.01)$ & $(0.46)$ & $(0.53)$ \\
\hline \multirow[t]{2}{*}{ Decile 2} & 0.77 & 0.73 & 0.70 & $0.99^{*}$ & 0.74 & 0.28 & 0.58 & -0.06 & 0.39 & -0.03 \\
\hline & $(0.24)$ & $(0.23)$ & $(0.29)$ & $(0.05)$ & $(0.24)$ & $(0.60)$ & $(0.51)$ & $(0.95)$ & $(0.54)$ & $(0.95)$ \\
\hline \multirow[t]{2}{*}{ Decile 3} & 0.06 & 0.71 & 0.56 & 0.40 & 0.65 & 0.23 & 0.36 & 0.47 & -0.23 & -0.28 \\
\hline & $(0.93)$ & $(0.26)$ & $(0.37)$ & $(0.41)$ & $(0.32)$ & $(0.64)$ & $(0.67)$ & $(0.52)$ & $(0.70)$ & $(0.57)$ \\
\hline \multirow[t]{2}{*}{ Decile 4} & -0.05 & 0.62 & -0.18 & 0.23 & 0.34 & 0.66 & 0.81 & 0.16 & 0.37 & 0.11 \\
\hline & (0.94) & $(0.28)$ & $(0.78)$ & $(0.88)$ & $(0.57)$ & $(0.20)$ & $(0.30)$ & $(0.80)$ & $(0.53)$ & (0.83) \\
\hline \multirow[t]{2}{*}{ Decile 5} & -0.40 & -0.09 & -0.07 & 0.03 & -0.47 & -0.04 & 0.20 & 0.38 & -0.58 & 0.63 \\
\hline & (0.55) & $(0.88)$ & $(0.91)$ & $(0.98)$ & $(0.43)$ & $(0.94)$ & $(0.74)$ & $(0.54)$ & $(0.34)$ & $(0.28)$ \\
\hline \multirow[t]{2}{*}{ Decile 6} & -0.18 & 0.08 & -0.23 & 0.02 & -0.32 & 0.34 & -0.72 & 0.14 & -0.08 & 0.53 \\
\hline & $(0.78)$ & (0.89) & $(0.70)$ & $(0.96)$ & $(0.62)$ & $(0.52)$ & $(0.20)$ & $(0.80)$ & $(0.90)$ & $(0.40)$ \\
\hline \multirow[t]{2}{*}{ Decile 7} & 0.15 & -0.42 & -0.18 & -0.11 & -0.26 & -0.12 & -0.20 & 0.13 & 0.40 & 0.99 \\
\hline & $(0.79)$ & $(0.47)$ & $(0.77)$ & $(0.80)$ & $(0.65)$ & $(0.85)$ & $(0.71)$ & $(0.79)$ & $(0.39)$ & $(0.15)$ \\
\hline \multirow[t]{2}{*}{ Decile 8} & 0.26 & -0.50 & 0.03 & -0.20 & -0.38 & -0.02 & -0.42 & 0.01 & -0.15 & 0.27 \\
\hline & (0.64) & $(0.46)$ & $(0.96)$ & (0.59) & (0.59) & (0.98) & $(0.33)$ & (0.98) & $(0.82)$ & (0.71) \\
\hline \multirow[t]{2}{*}{ Decile 9} & -0.18 & -0.77 & -0.61 & -0.45 & -0.01 & -0.99 & -0.56 & 0.20 & -0.22 & -0.18 \\
\hline & $(0.78)$ & $(0.34)$ & $(0.40)$ & $(0.50)$ & $(0.97)$ & $(0.11)$ & $(0.20)$ & $(0.72)$ & $(0.61)$ & $(0.84)$ \\
\hline \multirow[t]{2}{*}{ Decile 10 (Most Intangibles) } & -0.76 & -1.05 & -0.98 & -0.81 & -0.98 & -0.72 & $-0.90^{*}$ & 0.19 & -0.48 & -0.51 \\
\hline & $(0.21)$ & $(0.16)$ & $(0.18)$ & $(0.10)$ & $(0.10)$ & $(0.23)$ & $(0.05)$ & $(0.83)$ & $(0.34)$ & $(0.57)$ \\
\hline Decile 1-Decile 10 & $2.01^{* *}$ & $2.81^{* *}$ & $2.93^{* *}$ & $1.48^{*}$ & $2.60^{* *}$ & $1.93^{*}$ & $1.52^{*}$ & $-2.00^{* *}$ & 0.98 & 0.12 \\
\hline$(p$-value $)$ & $(0.01)$ & $(0.00)$ & $(0.00)$ & $(0.05)$ & $(0.00)$ & $(0.04)$ & $(0.04)$ & $(0.01)$ & $(0.22)$ & $(0.81)$ \\
\hline Quintile 5-Quintile 1 & $1.55^{*}$ & $2.02^{* *}$ & $2.10^{* *}$ & 0.98 & $1.95^{* *}$ & 1.12 & 1.04 & $-1.49^{*}$ & 0.16 & 0.08 \\
\hline$(p$-value $)$ & $(0.02)$ & $(0.01)$ & $(0.00)$ & $(0.09)$ & $(0.01)$ & $(0.06)$ & $(0.10)$ & $(0.05)$ & $(0.75)$ & $(0.91)$ \\
\hline
\end{tabular}

The table reports the portfolio level four-factor alphas from monthly net excess returns in quarter $t+2$ of the funds in decile portfolios based on various measures mutual funds' exposure to intangibles-intensive firms. Column (1)-(6) sort funds based on R\&D as the measure of intangibles assets. In column (7), funds are sorted based on the value-weighted number of patents granted to a firm in the prior year. In column (8)-(10), funds are sorted based on the value-weighted ratio of PPE expenses to total assets, advertising expenses to PPE, and total intangibles as reported in accounting statements to PPE. The $p$-values based on Newey-West robust standard errors with a lag length of 12 months are reported in parentheses. ${ }^{* *},{ }^{*}$ represent statistical significance at the $1 \%$ and $5 \%$ level. 
Table 10

Portfolios of Mutual Funds Sorted on Proxies for Valuation Difficulty and Portfolio Concentration in Intangibles

\begin{tabular}{|c|c|c|c|c|c|c|}
\hline \multirow[b]{2}{*}{ IIR Quintile $(t)$} & \multicolumn{3}{|c|}{ Size Score } & \multicolumn{3}{|c|}{ Age Score } \\
\hline & Low $25 \%$ (High VD) & Medium 50\% & High 25\% (Low VD) & Low $25 \%$ (High VD) & Medium 50\% & High 25\% (Low VD) \\
\hline \multirow[t]{2}{*}{ Quintile 1 (Most Tangibles) } & $3.01^{* * *}$ & 0.59 & -0.45 & $2.27^{* *}$ & 0.95 & -0.55 \\
\hline & $(0.00)$ & $(0.40)$ & $(0.26)$ & $(0.01)$ & $(0.07)$ & $(0.23)$ \\
\hline \multirow[t]{2}{*}{ Quintile 2} & $1.83^{* *}$ & -0.06 & -0.72 & 0.79 & 0.96 & -0.62 \\
\hline & $(0.01)$ & $(0.91)$ & $(0.18)$ & $(0.39)$ & $(0.10)$ & $(0.12)$ \\
\hline \multirow[t]{2}{*}{ Quintile 3} & $1.66^{*}$ & -0.39 & -0.58 & -0.24 & -0.34 & -0.19 \\
\hline & $(0.03)$ & $(0.40)$ & $(0.17)$ & $(0.81)$ & $(0.45)$ & $(0.59)$ \\
\hline \multirow[t]{2}{*}{ Quintile 4} & 0.33 & -0.07 & -0.77 & -1.11 & -0.21 & -0.63 \\
\hline & $(0.74)$ & $(0.91)$ & $(0.10)$ & $(0.20)$ & $(0.69)$ & $(0.15)$ \\
\hline \multirow[t]{2}{*}{ Quintile 5 (Most Intangibles) } & $-2.42^{*}$ & $-1.58^{*}$ & $-1.89^{* *}$ & $-2.44^{* *}$ & -0.55 & -1.64 \\
\hline & $(0.02)$ & $(0.04)$ & $(0.00)$ & $(0.00)$ & $(0.54)$ & $(0.06)$ \\
\hline Quintile 1-5 & $5.43^{* *}$ & $2.17^{* *}$ & $1.44^{*}$ & $4.71^{* *}$ & $1.50^{* *}$ & 1.09 \\
\hline \multirow[t]{2}{*}{$(p$-value $)$} & $(0.00)$ & $(0.01)$ & $(0.05)$ & $(0.00)$ & $(0.01)$ & $(0.08)$ \\
\hline & \multicolumn{3}{|c|}{ Book-to-Market Score } & \multicolumn{3}{|c|}{ Trading Volume Score } \\
\hline IIR Quintile $(t)$ & Low 25\% (High VD) & Medium 50\% & High 25\% (Low VD) & High 25\% (High VD) & Medium 50\% & Low $25 \%$ (Low VD) \\
\hline \multirow[t]{2}{*}{ Quintile 1 (Most Tangibles) } & -0.05 & 0.37 & $1.21^{*}$ & $1.01^{*}$ & 1.08 & 1.02 \\
\hline & $(0.93)$ & $(0.46)$ & $(0.03)$ & $(0.05)$ & $(0.12)$ & $(0.06)$ \\
\hline \multirow[t]{2}{*}{ Quintile 2} & -0.32 & -0.08 & 0.29 & -0.57 & 0.28 & 0.09 \\
\hline & $(0.66)$ & $(0.88)$ & $(0.55)$ & $(0.56)$ & $(0.65)$ & $(0.84)$ \\
\hline \multirow[t]{2}{*}{ Quintile 3} & -0.69 & -0.41 & 0.29 & -1.13 & 0.00 & 0.62 \\
\hline & $(0.42)$ & $(0.31)$ & $(0.50)$ & $(0.17)$ & $(1.00)$ & $(0.19)$ \\
\hline \multirow[t]{2}{*}{ Quintile 4} & $-1.82^{*}$ & -0.37 & 0.25 & -0.99 & -0.43 & -0.11 \\
\hline & $(0.02)$ & $(0.45)$ & $(0.61)$ & $(0.17)$ & $(0.48)$ & $(0.82)$ \\
\hline \multirow[t]{2}{*}{ Quintile 5 (Most Intangibles) } & $-3.51^{* *}$ & -1.01 & 0.20 & $-2.91^{* *}$ & -0.80 & -0.25 \\
\hline & $(0.00)$ & $(0.09)$ & $(0.73)$ & $(0.01)$ & $(0.07)$ & $(0.55)$ \\
\hline Quintile 1-5 & $3.46^{* *}$ & $1.38^{*}$ & 1.01 & $3.92^{* *}$ & $1.88^{*}$ & $1.27^{*}$ \\
\hline ( $p$-value) & $(0.00)$ & $(0.05)$ & $(0.15)$ & $(0.00)$ & $(0.02)$ & $(0.04)$ \\
\hline
\end{tabular}

Funds are sorted into three groups representing the funds with the lowest 25\%, middle 50\%, and highest 25\% in quarter $t$ based on valuation difficulty (VD) of portfolios: Size Score, Age Score, Book-to-Market Score, or Trading Volume Score. Size Score, Age Score, Book-to-Market Score, and Trading Volume Score are the value-weighted DGTW size quintile, firm age, DGTW book-to-market quintile, and mean monthly trading volume in the most recent quarter across all the fund's holdings in the quarter, respectively. Within each group, funds are then sorted into quintiles based on IIR. The table reports the portfolio level four-factor alphas from monthly net excess returns in quarter $t+2$ of the quintile portfolios within each Low/Medium/High VD group. The $p$-values (in parentheses) are based on Newey-West robust standard errors (lag length of 12 months). ${ }^{* *},{ }^{*}$ represent statistical significance at the $1 \%$ and 5\% level. 
Table 11

Multivariate Regressions Explaining Attributes of Fund Returns

\begin{tabular}{|c|c|c|c|c|c|c|c|c|c|c|c|c|}
\hline & \multicolumn{3}{|c|}{ Excess Return } & \multicolumn{3}{|c|}{ Four-factor Alpha } & \multicolumn{3}{|c|}{ Volatility } & \multicolumn{3}{|c|}{ Maximum Return } \\
\hline & $(1)$ & $(2)$ & (3) & (4) & $(5)$ & (6) & $(7)$ & $(8)$ & (9) & $(10)$ & $(11)$ & $(12)$ \\
\hline$I I R$ & $\begin{array}{l}-0.148^{* *} \\
(0.00)\end{array}$ & $\begin{array}{l}-0.028^{*} \\
(0.02)\end{array}$ & $\begin{array}{l}-0.031^{* *} \\
(0.01)\end{array}$ & $\begin{array}{l}-0.027^{* *} \\
(0.00)\end{array}$ & $\begin{array}{l}-0.019^{* *} \\
(0.00)\end{array}$ & $\begin{array}{l}-0.016^{* *} \\
(0.00)\end{array}$ & $\begin{array}{l}0.017^{* *} \\
(0.00)\end{array}$ & $\begin{array}{l}0.010^{* *} \\
(0.01)\end{array}$ & $\begin{array}{l}0.017^{* *} \\
(0.00)\end{array}$ & $\begin{array}{l}0.052^{* *} \\
(0.00)\end{array}$ & $\begin{array}{l}0.201^{* *} \\
(0.01)\end{array}$ & $\begin{array}{l}0.379^{* *} \\
(0.00)\end{array}$ \\
\hline IIR x Lagged IMT Return & & $\begin{array}{c}-0.366^{*} \\
(0.03)\end{array}$ & $\begin{array}{l}-0.562^{* *} \\
(0.00)\end{array}$ & & $\begin{array}{c}-0.131^{*} \\
(0.04)\end{array}$ & $\begin{array}{l}-0.157^{* *} \\
(0.00)\end{array}$ & & $\begin{array}{l}0.115^{* *} \\
(0.00)\end{array}$ & $\begin{array}{l}0.115^{* *} \\
(0.00)\end{array}$ & & $\begin{array}{l}1.814^{* *} \\
(0.00)\end{array}$ & $\begin{array}{l}1.796^{* *} \\
(0.00)\end{array}$ \\
\hline IIR x MOM Score & & $\begin{array}{l}-0.042^{* *} \\
(0.01)\end{array}$ & $\begin{array}{l}-0.035^{* *} \\
(0.00)\end{array}$ & & $\begin{array}{l}-0.028^{* *} \\
(0.00)\end{array}$ & $\begin{array}{l}-0.026^{* *} \\
(0.00)\end{array}$ & & $\begin{array}{l}0.001 \\
(0.23)\end{array}$ & $\begin{array}{l}0.000 \\
(0.27)\end{array}$ & & $\begin{array}{l}0.026 \\
(0.23)\end{array}$ & $\begin{array}{l}0.011^{*} \\
(0.05)\end{array}$ \\
\hline Lagged IMT Return & & $\begin{array}{l}0.811^{\text {** }} \\
(0.00)\end{array}$ & $\begin{array}{l}0.860^{* *} \\
(0.00)\end{array}$ & & $\begin{array}{l}0.196^{* *} \\
(0.00)\end{array}$ & $\begin{array}{l}0.190^{* *} \\
(0.00)\end{array}$ & & $\begin{array}{l}-0.034^{* *} \\
(0.00)\end{array}$ & $\begin{array}{l}-0.038^{* *} \\
(0.00)\end{array}$ & & $\begin{array}{l}-1.701^{* *} \\
(0.00)\end{array}$ & $\begin{array}{l}-1.791^{* *} \\
(0.00)\end{array}$ \\
\hline MOM Score & & $\begin{array}{l}-0.008^{*} \\
(0.03)\end{array}$ & $\begin{array}{r}-0.002 \\
(0.36)\end{array}$ & & $\begin{array}{l}0.001 \\
(0.56)\end{array}$ & $\begin{array}{l}-0.003^{*} \\
(0.03)\end{array}$ & & $\begin{array}{l}0.002^{* *} \\
(0.00)\end{array}$ & $\begin{array}{l}0.004^{* *} \\
(0.00)\end{array}$ & & $\begin{array}{l}0.015^{* *} \\
(0.01)\end{array}$ & $\begin{array}{l}0.061^{* *} \\
(0.00)\end{array}$ \\
\hline IIR $\times \log ($ Fund Age $)$ & & $\begin{array}{l}0.026^{* *} \\
(0.00)\end{array}$ & $\begin{array}{l}0.019^{* *} \\
(0.00)\end{array}$ & & $\begin{array}{l}0.008^{*} \\
(0.03)\end{array}$ & $\begin{array}{l}0.009^{* *} \\
(0.00)\end{array}$ & & $\begin{array}{l}-0.003^{* *} \\
(0.00)\end{array}$ & $\begin{array}{l}-0.003^{* *} \\
(0.00)\end{array}$ & & $\begin{array}{l}-0.078^{* *} \\
(0.00)\end{array}$ & $\begin{array}{l}-0.102^{* *} \\
(0.00)\end{array}$ \\
\hline IIR $\times \log$ (Manager Tenure) & & $\begin{array}{l}0.013^{*} \\
(0.04)\end{array}$ & $\begin{array}{l}0.007 \\
(0.10)\end{array}$ & & $\begin{array}{l}0.005 \\
(0.14)\end{array}$ & $\begin{array}{l}0.004 \\
(0.26)\end{array}$ & & $\begin{array}{l}-0.002^{* *} \\
(0.00)\end{array}$ & $\begin{array}{l}-0.001^{*} \\
(0.04)\end{array}$ & & $\begin{array}{l}-0.077^{* *} \\
(0.00)\end{array}$ & $\begin{array}{l}-0.024^{* *} \\
(0.00)\end{array}$ \\
\hline $\log ($ Fund Age) & & $\begin{array}{l}-0.017^{* *} \\
(0.00)\end{array}$ & $\begin{array}{r}-0.002 \\
(0.41)\end{array}$ & & $\begin{array}{l}-0.012^{* *} \\
(0.00)\end{array}$ & $\begin{array}{l}-0.004^{* *} \\
(0.00)\end{array}$ & & $\begin{array}{l}0.001^{* *} \\
(0.01)\end{array}$ & $\begin{array}{l}0.001^{\text {*** }} \\
(0.00)\end{array}$ & & $\begin{array}{l}0.014^{* *} \\
(0.01)\end{array}$ & $\begin{array}{l}0.024^{* *} \\
(0.00)\end{array}$ \\
\hline log (Manager Tenure) & & $\begin{array}{l}-0.010^{* *} \\
(0.00)\end{array}$ & $\begin{array}{l}0.000 \\
(0.98)\end{array}$ & & $\begin{array}{r}-0.000 \\
(0.85)\end{array}$ & $\begin{array}{l}0.003^{* *} \\
(0.00)\end{array}$ & & $\begin{array}{l}0.001^{* *} \\
(0.00)\end{array}$ & $\begin{array}{l}-0.000 \\
(0.22)\end{array}$ & & $\begin{array}{l}0.020^{* * *} \\
(0.00)\end{array}$ & $\begin{array}{r}-0.002 \\
(0.47)\end{array}$ \\
\hline Fund fixed-effects & Yes & Yes & No & Yes & Yes & No & Yes & Yes & No & Yes & Yes & No \\
\hline Fund controls & No & No & Yes & No & No & Yes & No & No & Yes & No & No & Yes \\
\hline Objective fixed-effects & No & No & Yes & No & No & Yes & No & No & Yes & No & No & Yes \\
\hline Year fixed-effects & No & Yes & Yes & No & Yes & Yes & No & Yes & Yes & No & Yes & Yes \\
\hline No. of observations & 285,970 & 279,452 & 166,449 & 265,773 & 259,255 & 146,252 & 274,827 & 267,711 & 154,708 & 274,827 & 267,711 & 154,708 \\
\hline$\underline{R \text {-squared }}$ & 0.013 & 0.100 & 0.106 & 0.021 & 0.030 & 0.019 & 0.265 & 0.751 & 0.676 & 0.255 & 0.597 & 0.489 \\
\hline
\end{tabular}

The dependent variables are annualized monthly excess returns (columns (1)-(3)), monthly four-factor alpha (columns (4)-(6)), Volatility (columns (7)-(9)), and Maximum Return (columns (10)-(12)) over the three months in each quarter $t+2$, respectively. Volatility and Maximum

Return in a month are the standard deviation of monthly excess returns and the maximum monthly excess return over the next 12 months, respectively. Lagged IMT Return is the mean IMT portfolio return (defined in Table 5) over the six months $t-5$ to $t$. Fund controls (suppressed) are Size Score, Book-to-Market Score, Expense Ratio, Turnover Ratio, log (TNA), Industry Concentration, Active Share, and Past Flows. All specifications include year fixed effects, and fund or objective fixed effects. The $p$-values (in parentheses) are based on Newey-West standard errors with a lag length of 12 months, and account for clustering at the fund level. ${ }^{* *},{ }^{*}$ denote significance at the $1 \%$ and $5 \%$ level. 